\title{
The Reaction of Hydrogen Halides with Tetrahydroborate Anion and Hexahydro-closo-hexaborate Dianion
}

\author{
Igor E. Golub*(D), Oleg A. Filippov (D), Natalia V. Belkova $(D)$, Lina M. Epstein and Elena S. Shubina *(D) \\ A. N. Nesmeyanov Institute of Organoelement Compounds, Russian Academy of Sciences (INEOS RAS), \\ 28, Vavilova St, 119991 Moscow, Russia; h-bond@ineos.ac.ru (O.A.F.); nataliabelk@ineos.ac.ru (N.V.B.); \\ epst@ineos.ac.ru (L.M.E.) \\ * Correspondence: seraph347@gmail.com (I.E.G.); shu@ineos.ac.ru (E.S.S.)
}

Citation: Golub, I.E.; Filippov, O.A.; Belkova, N.V.; Epstein, L.M.; Shubina, E.S. The Reaction of Hydrogen Halides with Tetrahydroborate Anion and Hexahydro-closo-hexaborate Dianion. Molecules 2021, 26, 3754. https://doi.org/10.3390/

molecules26123754

Academic Editor: Antonio Zucca

Received: 28 April 2021

Accepted: 15 June 2021

Published: 20 June 2021

Publisher's Note: MDPI stays neutral with regard to jurisdictional claims in published maps and institutional affiliations.

Copyright: (c) 2021 by the authors. Licensee MDPI, Basel, Switzerland. This article is an open access article distributed under the terms and conditions of the Creative Commons Attribution (CC BY) license (https:// creativecommons.org/licenses/by/ $4.0 /)$.

\begin{abstract}
The mechanism of the consecutive halogenation of the tetrahydroborate anion $\left[\mathrm{BH}_{4}\right]^{-}$by hydrogen halides $(\mathrm{HX}, \mathrm{X}=\mathrm{F}, \mathrm{Cl}, \mathrm{Br})$ and hexahydro-closo-hexaborate dianion $\left[\mathrm{B}_{6} \mathrm{H}_{6}\right]^{2-}$ by $\mathrm{HCl}$ via electrophile-induced nucleophilic substitution (EINS) was established by ab initio DFT calculations $[\mathrm{M} 06 / 6-311++\mathrm{G}(\mathrm{d}, \mathrm{p})$ and wB97XD/6-311++G(d,p)] in acetonitrile $(\mathrm{MeCN})$, taking into account nonspecific solvent effects (SMD model). Successive substitution of $\mathrm{H}^{-}$by $\mathrm{X}^{-}$resulted in increased electron deficiency of borohydrides and changes in the character of boron atoms from nucleophilic to highly electrophilic. This, in turn, increased the tendency of the B-H bond to transfer a proton rather than a hydride ion. Thus, the regularities established suggested that it should be possible to carry out halogenation more selectively with the targeted synthesis of halogen derivatives with a low degree of substitution, by stabilization of $\mathrm{H}_{2}$ complex, or by carrying out a nucleophilic substitution of $\mathrm{B}-\mathrm{H}$ bonds activated by interaction with Lewis acids $\left(\mathrm{BL}_{3}\right)$.
\end{abstract}

Keywords: borohydride; polyhedral closo-borane; proton transfer; Lewis acidity; hydride donor ability; DFT calculations

\section{Introduction}

Halogenated borane derivatives are successfully used as Lewis acids [1,2], as Brønsted superacids [3-5], as weakly coordinating anions [6,7], and as components of ionic liquids [8] and solid-state electrolytes $[9,10]$. Radio-halogenated boron clusters are used in tumor imaging and therapy [11].

Di- and tri-substituted halogenated derivatives of $\mathrm{BH}_{4}{ }^{-}\left(\mathrm{BH}_{2} \mathrm{X}_{2}{ }^{-}\right.$and $\left.\mathrm{BHX}_{3}{ }^{-}\right)$can be obtained through $\mathrm{MBH}_{4}-\mathrm{MBX}_{4}(\mathrm{X}=\mathrm{F}, \mathrm{Cl})$ exchange [12-14]. However, this reaction always leads to a mixture of products (due to disproportionation and low selectivity of the process), as well as to the formation of by-products as a result of the interaction of substitution products with the initial reagents [12]. Another possible approach to the synthesis of halogenated derivatives is direct halogenation; however, the reported halogenation of $\mathrm{BH}_{4}{ }^{-}$by the reaction with HF has resulted in the formation of a mixture of substitution products [14]. However, as exemplified in [15], the use of ${ }^{1} \mathrm{H}$ NMR monitoring during the bubbling of $t \mathrm{BuNH}_{2} \cdot \mathrm{BH}_{3}$ with anhydrous hydrogen halides $\mathrm{HX}(\mathrm{X}=\mathrm{F}, \mathrm{Cl}, \mathrm{Br})$ allows for the reaction to be stopped when the desired halogenation product is formed.

The halogenated derivatives of $\left[\mathrm{B}_{6} \mathrm{H}_{6}\right]^{2-}$ are typically obtained by the reaction in highly alkaline aqueous solutions in the presence of free halogens $X_{2}(X=C l, B r, I)[16,17]$. However, this approach always results in mixtures of several components. Moreover, due to the fast rate of halogenation, the mono- and dihalogen derivatives are available as minor products, while tri- and penta-substituted derivatives are major products. Therefore, the use of preparative scale ion exchange column chromatography is essential for the isolation of pure compounds. However, for geometrical isomers with the same degree of halogenation, the difference in phase mobility is small (5-15\%); thus, their separation could be achieved only by repeated ion exchange column chromatography [18]. 
Due to these factors, there are difficulties in the synthesis of halogen-derived borohydrides. These reactions are not selective; in a general case, a mixture of various substitution products is obtained, and to isolate the desired substitution product, additional separation and purification are necessary. To overcome these difficulties and develop an approach for the targeted synthesis of these compounds, we undertook DFT calculations for the halogenation of tetrahydroborate-anion $\left(\mathrm{BH}_{4}{ }^{-}\right.$, which is the smallest available boron hydride model) and hexahydro-closo-hexaborate dianion $\left(\left[\mathrm{B}_{6} \mathrm{H}_{6}\right]^{2-}\right.$, which is the smallest stable closo-borane anion) with hydrogen halides.

Previously, a DFT investigation of halogenation was performed, albeit only for $\left[\mathrm{B}_{6} \mathrm{H}_{6}\right]^{2-}$ on the example of interaction with $\operatorname{HOX}(\mathrm{X}=\mathrm{Cl}, \mathrm{Br})$ and only for the first two steps [17]. In the case of $\mathrm{BH}_{4}{ }^{-}$, the DFT study of the stepwise hydrolysis [19] and alcoholysis [20] were reported. Its interaction with strong acids was investigated only for the first reaction step - and only for $\mathrm{CF}_{3} \mathrm{OH}$ [21]. From one side, hydrogen halides (such as $\mathrm{HCl}$ and $\mathrm{HBr}$ ) are strong inorganic acids which violently react with $\mathrm{BH}_{4}{ }^{-}$and cause halogenation of closo-boranes via the electrophile-induced nucleophilic substitution (EINS) mechanism [22,23]. From the other side, the halogen is the electron-withdrawing group (EWG), which should increase electron deficiency at the boron atom, altering the reactivity of the B-H bond in halogen-substituted derivatives. In this regard, it was interesting to investigate the direct halogenation of $\mathrm{BH}_{4}{ }^{-}$and $\left[\mathrm{B}_{6} \mathrm{H}_{6}\right]^{2-}$ by hydrogen halides.

In the course of our work, we began with the DFT study of the mechanism of direct successive halogenation using the example of the reaction of $\mathrm{BH}_{4}{ }^{-}$with $\mathrm{HX}(\mathrm{X}=\mathrm{F}, \mathrm{Cl}, \mathrm{Br})$ in acetonitrile $(\mathrm{MeCN})$. Then, using the knowledge gained, we studied halogenation of $\left[\mathrm{B}_{6} \mathrm{H}_{6}\right]^{2-}$ with $\mathrm{HCl}$ in $\mathrm{MeCN}$, which proceeded as an electrophile-induced nucleophilic substitution (EINS) process. Thus, in this work, a principal mechanism of direct halogenation was established for $\mathrm{BH}_{4}{ }^{-}$and $\left[\mathrm{B}_{6} \mathrm{H}_{6}\right]^{2-}$. The changes in the reactivity of the $\mathrm{B}-\mathrm{H}$ bond entailed by halogens' introduction were evaluated via calculations of their hydride donor ability (HDA) and proton donor ability (PDA). Hydride donor ability (HDA)-i.e., thermodynamic hydridicity, defined as the Gibbs free energy $\left(\Delta \mathrm{G}^{\circ}\left[\mathrm{H}^{-}\right]\right)$value for the reaction of hydride ion $\left(\mathrm{H}^{-}\right)$detachment-is an important reactivity characteristic in transition metals $[24,25]$ and the main group hydrides [20,26-29]. Similarly, the proton donor ability (PDA), i.e., thermodynamic acidity, was calculated as the Gibbs free energy $\left(\Delta \mathrm{G}^{\circ}\left[\mathrm{H}^{+}\right]\right)$for the reaction of proton $\left(\mathrm{H}^{+}\right)$detachment. In the case of anionic boron hydrides, both HDA and PDA parameters have been estimated by only a few researchers [30,31].

\section{Results and Discussion}

\subsection{Interaction Tetrahydroborate-Anion with Hydrogen Halides}

In our previous work [20], we showed (by DFT investigation of stepwise alcoholysis of tetrahydroborate-anion $\mathrm{BH}_{4}{ }^{-}$) that first proton-hydride transfer is the rate-limiting stage of the reaction, and that the energy profile takes the form of a cascade, since the energy of each next transition state is lower than the one previous. That, in turn, is associated with a decrease in Lewis acidity of the corresponding neutral borane $(\mathrm{RO})_{\times} \mathrm{BH}_{(3-\mathrm{x})}$ and a weakening of $\mathrm{B}-\mathrm{H}$ bond in $\left[(\mathrm{RO})_{\mathrm{x}} \mathrm{BH}_{(4-\mathrm{x})}\right]^{-}(\mathrm{x}=0-3)$ anion entailed by the successive substitution of $\mathrm{H}^{-}$by $\mathrm{RO}^{-}$at the boron atom. Thus, the $\mathrm{B}-\mathrm{H}$ bond activation of $\mathrm{BH}_{4}{ }^{-}$and its ability to hydride transfer appeared to be crucial to this process.

It is known that alkaline tetrahydroborates react violently with concentrated mineral acids (such as $\mathrm{H}_{2} \mathrm{SO}_{4}, \mathrm{HF}$, etc.) [14,32], yielding the substituted products and diborane, which is formed as a result of interaction between the reaction products. However, as we demonstrated in [30], an introduction of EWG $\left(\mathrm{X}^{-}, \mathrm{X}=\mathrm{F}, \mathrm{Cl}, \mathrm{Br}\right)$ to boron atoms increases the Lewis acidity of the parent borane $\mathrm{BH}_{(3-\mathrm{x})} \mathrm{X}_{\mathrm{x}}$ and reduces the ability of $\mathrm{B}-\mathrm{H}$ bonds in $\left[\mathrm{BH}_{(4-\mathrm{x})} \mathrm{X}_{\mathrm{x}}\right]^{-}(\mathrm{x}=0-3)$ to hydride transfer. In this regard, it was interesting to investigate, in the current work, the reaction of $\mathrm{BH}_{4}{ }^{-}$with strong mineral acids such as hydrogen halides. For these purposes, we investigated this stepwise process of halogenation of $\mathrm{BH}_{4}{ }^{-}$with $\mathrm{HX}$ (where $\mathrm{X}=\mathrm{F}, \mathrm{Cl}, \mathrm{Br}$ ) in acetonitrile $(\mathrm{MeCN}$ ) at $\mathrm{M} 06 / 6-311++\mathrm{G}(\mathrm{d}, \mathrm{p}$ ) and $w B 97 X D / 6-311++G(d, p)$ levels of theory. 
The dihydrogen-bonded (DHB) complexes are active intermediates of the $\mathrm{BH}_{4}{ }^{-}$ reaction with HX [33] and HOR $[20,21,34,35]$. DHB complexes with hydrogen halides HX $\left(\mathrm{X}=\mathrm{F}, \mathrm{Cl}, \mathrm{Br}\right.$ ) found in this work (Table S1) were monodentate (except for $\mathrm{H}_{3} \mathrm{BH}^{-} \ldots \mathrm{HF}$ ) with $\mathrm{H} \cdots \mathrm{H}$ distances of $1.425-1.850 \AA$ and angles $\angle \mathrm{X}-\mathrm{H} \cdots \mathrm{H}=159-178^{\circ}$. Their structures were similar to those found in $\mathrm{BH}_{4}{ }^{-}$alcoholysis $[20,21]$, with the geometric parameters typical of DHB complexes [36-38]. It should be noted, that for $\left[\mathrm{H}_{2} \mathrm{XBH}\right]^{-}$and $\left[\mathrm{HX}_{2} \mathrm{BH}\right]^{-}(\mathrm{X}=\mathrm{F}, \mathrm{Cl}$, $\mathrm{Br}$ ) molecules, two coordination modes were found, where halogen atom $\mathrm{X}$ was located in trans- and cis-position to the dihydrogen-bonded HX molecules. The formation energies of DHB complexes with a halogen atom in trans-position are slightly less favorable than those of DHB complexes with $\mathrm{X}$ in cis-position; the difference in the Gibbs free energy of these two complexes, $\Delta \Delta \mathrm{G}_{f}^{\circ} \mathrm{MeCN}=\Delta \mathrm{G}_{f}^{\circ}{ }_{\mathrm{MeCN}}\left(\mathrm{INTn}^{\mathrm{DHB}}{ }_{\text {trans }}\right)-\Delta \mathrm{G}_{f}{ }^{\circ} \mathrm{MeCN}\left(\mathrm{INTn}^{\mathrm{DHB}}{ }_{\text {cis }}\right)$, reaches $1.8 \mathrm{kcal} / \mathrm{mol}$. Moreover, the transition states of $\mathrm{H}_{2}$ elimination (TSn ${ }^{\text {ELIM }}$ and TSn ${ }^{\text {CONC, }}$, see below) are energetically destabilized when $\mathrm{X}$ is located in trans-position, compared to those where $X$ is located in cis-position. The difference $\Delta \Delta \mathrm{G}^{\circ} \mathrm{MeCN}^{\ddagger}=\Delta \mathrm{G}^{\circ}{ }_{\mathrm{MeCN}}{ }^{\ddagger}\left(\mathbf{T S n}_{\text {trans }}\right)$ $-\Delta \mathrm{G}^{\circ}{ }_{\mathrm{MeCN}}{ }^{\ddagger}\left(\mathbf{T S n}_{\text {cis }}\right)$ can reach up to $2.2 \mathrm{kcal} / \mathrm{mol}$. Thus, herein, we considered only the configurations with $\mathrm{X}$ located in cis-position to HX.

Upon going from $\mathrm{HF}$ to $\mathrm{HBr}$, the enthalpy of DHB complexes' formation $\left(\Delta \mathrm{H}_{f}{ }^{\circ} \mathrm{MeCN}\right.$, Table S1) and other parameters characterizing the $\mathrm{H} \cdots \mathrm{H}$ interactions strength $\left(\mathrm{E}_{\mathrm{H} \cdots \mathrm{H}}\right.$ and $\mathrm{E}^{2}$ are given in Table S1, and Wiberg bond indices (WBI) and QTAIM delocalization indices (DI) - in Table S3) decreased, in agreement with the HX acidity and hydrogen bond donor strength [39].

Substitution of one $\mathrm{H}^{-}$by $\mathrm{X}^{-}(\mathrm{X}=\mathrm{F}, \mathrm{Cl}, \mathrm{Br})$ in $\mathrm{BH}_{4}^{-}$led to an increase of s-character of the B-H bond hybrid orbital in the resulting $\left[\mathrm{BH}_{3} \mathrm{X}\right]^{-}$, from $25.0 \%$ up to $31.9 \%$ (from $\mathrm{sp}^{3}$ to $\mathrm{sp}^{2}$, Table S3). In general, an increase of s-character of a B-H bond, as in the case of $\mathrm{BH}_{4}{ }^{-}$alcoholysis [20], is associated with strengthening of B-H bonds (according to QTAIM delocalization index, DI, Table S4) and weakening of DHB bonds. However, in the case of the $\mathrm{BH}_{4}{ }^{-}$reaction with $\mathrm{HF}$ for the $\mathrm{H}_{2} \mathrm{FBH}^{-} \ldots \mathrm{HF}$ and $\mathrm{HF}_{2} \mathrm{BH}^{-} \ldots \mathrm{HF}$ complexes (Figure 1), there was an increase of DHB interaction strength $\left(\mathrm{E}^{2}=19.2 \mathrm{kcal} / \mathrm{mol}\right.$ and $18.6 \mathrm{kcal} / \mathrm{mol}$, respectively, Table S1). In fluoroborohydrides, the strong electron-withdrawing inductive $\sigma$ effect - due to the large difference in boron and fluorine electronegativity $\left(\Delta \chi_{A-R}=2.1\right)[40]-$ led to the large positive charge on the boron atom $\left(1.53 \mathrm{for}_{\mathrm{BF}}\right.$ ) [41]. On the other hand, this effect was compensated by the strong back donation from nonbonding $2 \mathrm{p}_{\pi}$ electron pairs of $\mathrm{F}$ to vacant $2 \mathrm{p}_{\pi}$ (B) orbital of the same symmetry [42,43]. For $\mathrm{BCl}_{3}$ and $\mathrm{BBr}_{3}$, due to a larger size of $2 p_{\pi}$ orbitals, their effective overlap with vacant boron $2 p_{\pi}$ orbital decreased; therefore, back-donation for $\mathrm{BF}_{3}$ was stronger than for $\mathrm{BCl}_{3}$ and $\mathrm{BBr}_{3}$, and Lewis acidity decreased in the row $\mathrm{BF}_{3}>\mathrm{BH}_{3}>\mathrm{BCl}_{3}>\mathrm{BBr}_{3}$ (as can be seen from their hydride affinity values, $\mathrm{HA}_{298 \mathrm{~K}}$, Table $\mathrm{S} 3$ ).

The reaction of $\mathrm{BH}_{4}{ }^{-}$with $\mathrm{HX}$ (where $\mathrm{X}=\mathrm{F}, \mathrm{Cl}, \mathrm{Br}$ ) in acetonitrile $(\mathrm{MeCN}$ ) occurs as a successive proton-hydride transfer and $\mathrm{H}_{2}$ elimination, yielding $\left[\mathrm{BH}_{(4-\mathrm{x})} \mathrm{X}_{\mathrm{x}}\right]^{-}$ $(x=1-3)$ halogenated products (Figure 2, Figures S1 and S2). In the case of weak acids like $\mathrm{HF}\left(\mathrm{pK}_{\mathrm{a}}{ }^{\mathrm{MeCN}}{ }_{(\text {estim })}=25.2\right.$ [44]) only one product-like concerted transition state (TS) of proton-hydride transfer and $\mathrm{H}_{2}$ elimination was found ( $\mathrm{TS} \mathbf{C O N C}_{\mathrm{HF}}$, Figure 3). In the case of stronger acids $\mathrm{HCl}\left(\mathrm{pK}_{\mathrm{a}} \mathrm{MeCN}_{=} 10.3\right.$ [45]) or $\mathrm{HBr}\left(\mathrm{pK}_{\mathrm{a}}{ }^{\mathrm{MeCN}}=5.4\right.$ [45]), two TS's were observed: a reagent-like transition state of proton transfer $\left(\mathrm{TS1}^{\mathrm{PT}}{ }_{\mathrm{HCl}}\right)$ and a product-like transition state of $\mathrm{H}_{2}$ elimination (TS1 ${ }^{\mathrm{ELIM}_{\mathrm{HCl}}}$ ). Both concerted TS of proton-hydride transfer/ $\mathrm{H}_{2}$ elimination TSn ${ }^{\mathrm{CONC}}{ }_{\mathrm{HX}}$ and TS of $\mathrm{H}_{2}$ elimination TSn $^{\text {ELIM }}{ }_{\mathrm{HX}}$ (preceded by proton transfer step $\mathrm{TSn}^{\mathrm{PT}} \mathrm{HX}$ ) exhibited a similar triangle-shaped form of front-side nucleophilic substitution of $\mathrm{H}_{2}$ by halide-ion $\mathrm{X}^{-}$. The $\mathrm{B} \cdot \mathrm{H}_{2}$ and $\mathrm{H} \cdots \mathrm{H}$ distances (Tables S5 and S6) in TSn ${ }^{\text {ELIM }}{ }_{\text {HX }}$ could be considered indirect indicators of activation barrier height. With the increase of the activation energy, the $\mathrm{B} \cdots \mathrm{H}_{2}$ distances decreased for the borohydrides with EWG substituents, while at the same time, $\mathrm{H} \cdots \mathrm{H}$ distances shortened for weak proton donors (such as HF, ROH, Table S7). Similar transition states were described previously in a theoretical study of $\mathrm{BH}_{4}{ }^{-}$alcoholysis by weak $\left(\mathrm{MeOH}, \mathrm{CF}_{3} \mathrm{CH}_{2} \mathrm{OH}\right)$ and strong $\left(\mathrm{CF}_{3} \mathrm{OH}\right)$ proton donors [21]. 
159.3

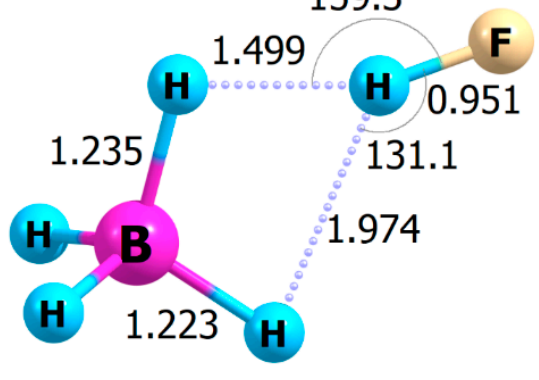

$\mathrm{BH}_{4}^{-\cdots H F}$

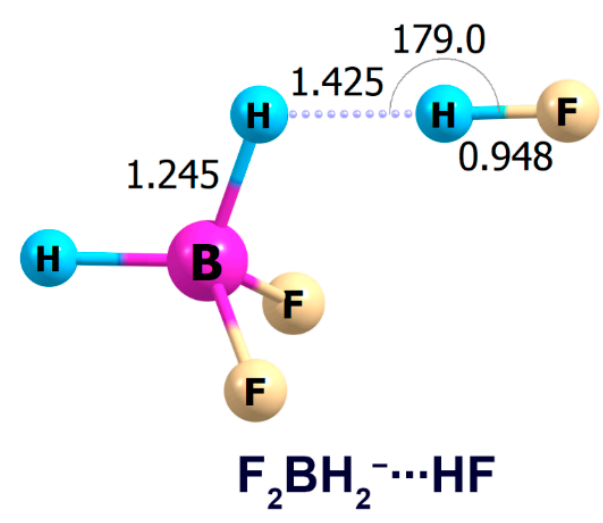

172.2

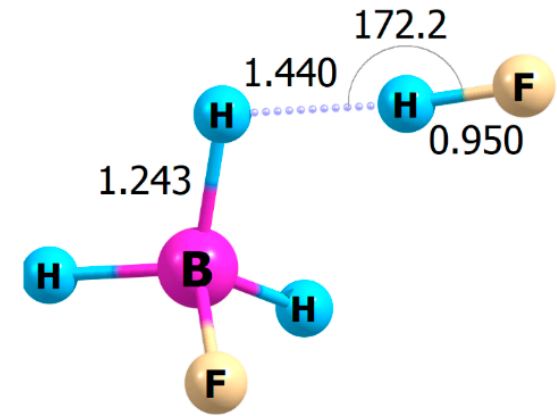

$\mathrm{FBH}_{3}-\cdots \mathrm{HF}$

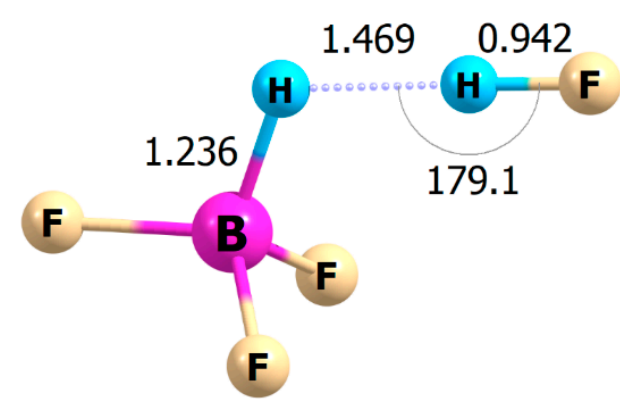

$\mathrm{F}_{3} \mathrm{BH}^{-\cdots} \cdot \mathrm{HF}$

Figure 1. M06-optimized geometries of DHB complexes of $\left[\mathrm{BH}_{(4-\mathrm{x})} \mathrm{F}_{\mathrm{X}}\right]^{-}(\mathrm{x}=0-3)$ with $\mathrm{HF}\left(\mathbf{I N T n}{ }^{\mathrm{DHB}}{ }_{\mathrm{HF}}\right)$. The $\mathrm{r}_{(\mathrm{X} \cdots \mathrm{Y})}$ bond distances and $\angle \mathrm{H} \cdots \mathrm{HF}$ angles shown are in $\AA$ and ${ }^{\circ}$, respectively.

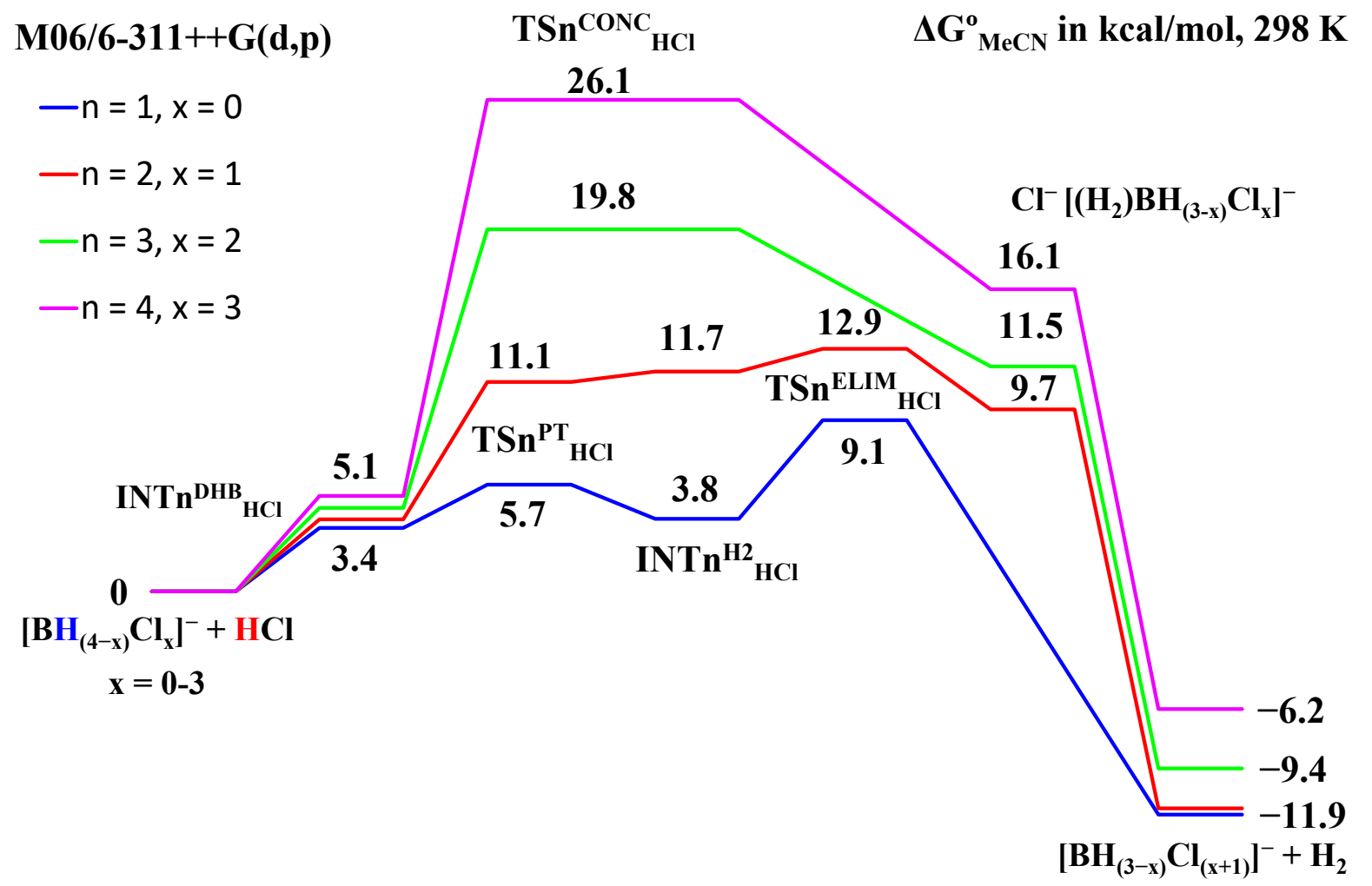

Figure 2. M06-calculated energy profile $\left(\Delta \mathrm{G}^{\circ} \mathrm{MeCN}\right.$ in $\left.\mathrm{kcal} / \mathrm{mol}\right)$ of the stepwise reaction of $\mathrm{BH}_{4}^{-}$with $\mathrm{HCl}$ in $\mathrm{MeCN}$. 


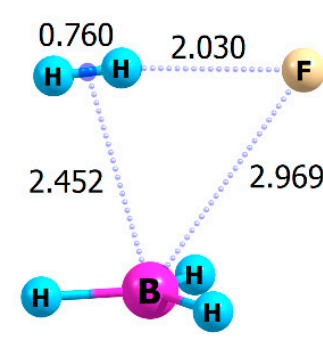

$\mathrm{TS}_{\text {HF }}^{\text {CONC }}$
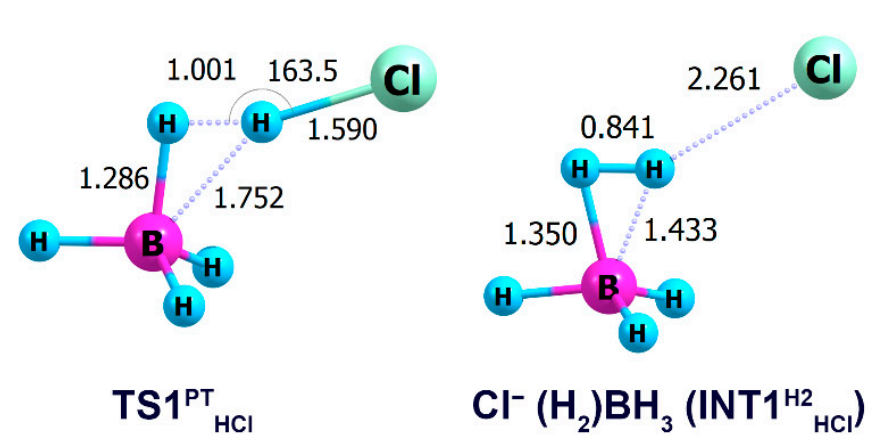

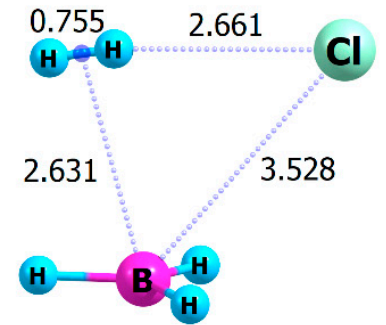

TS1 $_{\text {ELIM }}^{\text {HCI }}$

Figure 3. M06-optimized geometries of transition states (TS) and $\mathrm{H}_{2}$ reaction intermediates (INT ${ }^{\mathrm{H} 2}$ ) for the first stage of reaction between $\mathrm{BH}_{4}{ }^{-}$with $\mathrm{HX}(\mathrm{X}=\mathrm{F}, \mathrm{Cl})$ : concerted transition state of proton-hydride transfer and $\mathrm{H}_{2}$ elimination for

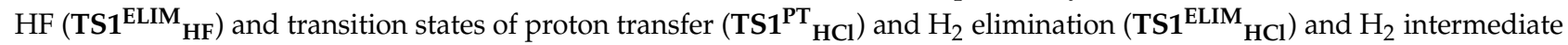
$\left(\mathrm{Cl}^{-}\left(\eta^{2}-\mathrm{H}_{2}\right) \mathrm{BH}_{3}, \mathrm{INT1}^{\mathrm{H} 2}{ }_{\mathrm{HCl}}\right)$ for $\mathrm{HCl}$. The $\mathrm{r}_{(\mathrm{X} \cdots \mathrm{Y})}$ bond distances and $\angle \mathrm{H} \cdots \mathrm{HF}$ angles shown are in $\AA$ and in ${ }^{\circ}$, respectively.

In the case of strong acids (like $\mathrm{HCl}, \mathrm{HBr}$ ), the formation of a metastable $\mathrm{H}_{2}$ intermediate $\mathrm{X}^{-}\left(\eta^{2}-\mathrm{H}_{2}\right) \mathrm{BH}_{3}\left(\mathbf{I N T n}{ }^{\mathbf{H} 2}\right)$ was observed (Figure 3). This resembled the intermediates of transition metal hydrides' protonation [46], which have also been proposed for the protonation of main group element hydrides [21,47-51]. It should be noted that INTn ${ }^{\mathrm{H} 2}$ was formed only at the first and second reaction step for $\mathrm{HCl}$, and at the first step for $\mathrm{HBr}$. This was due to an increase in electron deficiency of $\mathrm{BH}_{2} \mathrm{Cl}, \mathrm{BH}_{2} \mathrm{Br}$, and $\mathrm{BHCl}_{2}$ fragments, strengthening of $\mathrm{B}-\mathrm{H}$ and $\mathrm{X} \cdots \mathrm{H}(\mathrm{H})(\mathrm{X}=\mathrm{Cl}, \mathrm{Br})$ bonds, and a decrease of the donation from $\sigma(\mathrm{B}-\mathrm{R})$ (where $\mathrm{R}=\mathrm{H}, \mathrm{Cl}, \mathrm{Br}$ ) to $\sigma^{*}\left(\mathrm{H}-\mathrm{H}-\mathrm{B}\right.$ ), which ultimately destabilized the $\mathrm{H}_{2}$ intermediate (Table S2). It should be noted that $\sigma(\mathrm{B}-\mathrm{R})$ to $\sigma^{*}(\mathrm{H}-\mathrm{H}-\mathrm{B})$ donation from $\mathrm{R}$ group in trans position to $\mathrm{H}_{2}$ complex was the greatest $\left(\mathbf{E}^{2}{ }_{1}=8.8-13.3 \mathrm{kcal} / \mathrm{mol}\right)$ and had a key effect on the stabilization of $\left(\eta^{2}-\mathrm{H}_{2}\right)$ complex. This is also in line with the less energy-demanding attack of $\mathrm{HX}$ in the case of $\left[\mathrm{H}_{2} \mathrm{XBH}\right]^{-}$and $\left[\mathrm{HX}_{2} \mathrm{BH}\right]^{-}$bearing $\mathrm{X}$ in trans-position to $\mathrm{HX}$, in comparison to complexes with $\mathrm{X}$ in cis-position.

Thus, for the appearance of the transition state of proton transfer, which is absent in the case of weak acids and leads to the $\left(\eta^{2}-\mathrm{H}_{2}\right)$ complex formation, two conditions must apparently be satisfied. First, the $\mathrm{pK}_{\mathrm{a}}$ of the acid should be greater than the $\mathrm{pK}_{\mathrm{a}}$ of $\mathrm{H}_{3} \mathrm{~B}\left(\eta^{2}-\mathrm{H}_{2}\right)$ and, second, $\mathrm{R}_{3} \mathrm{~B}$ borane should be a good Lewis acid; at that, $\sigma(\mathrm{B}-\mathrm{R})$ orbital (such as $\mathrm{R}=\mathrm{H}, \mathrm{SiH}_{3}, \mathrm{SiF}_{3}[51]$ ) should donate to $\sigma^{*}(\mathrm{~B}-\mathrm{H}-\mathrm{H})$ orbital and $\mathrm{R}$ should not be able to $\pi$-back-donate to a vacant $2 \mathrm{p}_{\pi}(\mathrm{B})$ orbital.

In addition, a strong acid can significantly lower the activation energy of the 2nd reaction stage-that is, the $\mathrm{H}_{2}$ elimination. However, the process of $\mathrm{H}_{2}$ elimination will still be rate-limiting and will always have the highest value of the activation barrier, because of the relatively high B-H bond strength and its hydride transfer ability. In this regard, the reactivity of substituted borohydrides in reactions involving hydride transfer can be evaluated via their hydride donor ability $\left(\mathrm{HDA}_{\mathrm{MeCN}}\right.$, Table S3). In the case of $\mathrm{BH}_{4}{ }^{-}$ reaction with $\mathrm{HF}$ (Figures $\mathrm{S} 1$ and S2), the substitution led to $\mathrm{HDA}_{\mathrm{MeCN}}$ values of $\left[\mathrm{BH}_{3} \mathrm{~F}\right]^{-}$, $\left[\mathrm{BH}_{2} \mathrm{~F}_{2}\right]^{-}$and $\left[\mathrm{BHF}_{3}\right]^{-}$, reduced in comparison with $\mathrm{BH}_{4}{ }^{-}(54.64 \mathrm{kcal} / \mathrm{mol}, 53.12 \mathrm{kcal} / \mathrm{mol}$ and $61.08 \mathrm{kcal} / \mathrm{mol}$ vs. $64.86 \mathrm{kcal} / \mathrm{mol}$, respectively, for their Li salts; Table S3). As a result, the activation energy decreased by 7.6 and $2.4 \mathrm{kcal} / \mathrm{mol}$ for the reaction with the 2 nd and $3 \mathrm{rd}$ molecule of HF. However, it increased by $6.3 \mathrm{kcal} / \mathrm{mol}$ at the last stage (Table 1). Thus, the reaction of $\mathrm{BH}_{4}{ }^{-}$with $\mathrm{HF}$ followed a trend similar to that of THF. $\mathrm{BH}_{3}$ and $\mathrm{Me}_{2} \mathrm{NH} \cdot \mathrm{BH}_{3}$ alcoholysis by $\left(\mathrm{CF}_{3}\right)_{2} \mathrm{CHOH}[20,52]$. 
Table 1. Activation barriers $\left(\Delta \mathrm{G}^{\ddagger} \mathrm{MeCN}\right.$, in $\left.\mathrm{kcal} / \mathrm{mol}\right)$ for $\mathbf{T S n}^{\mathrm{CONC}_{\mathbf{H X}}}\left(\right.$ or $\left.\mathbf{T S n}^{\mathrm{PT}}{ }_{\mathbf{H X}} / \mathrm{TSn}^{\mathrm{ELIM}}{ }_{\mathbf{H X}}\right)$ in the step-wise reaction of $\mathrm{BH}_{4}{ }^{-}$with hydrogen halides in MeCN, computed at the M06/6-311++G(d,p) theory level relative to the corresponding DHB complexes.

\begin{tabular}{|c|c|c|c|}
\hline n & $\frac{\mathrm{HF}}{\mathrm{pK}_{\mathrm{a}}^{\mathrm{MeCN}}=25.2^{\mathrm{a}}}$ & $\begin{array}{c}\mathrm{HCl} \\
\mathrm{pK}_{\mathrm{a}}{ }^{\mathrm{MeCN}}=10.3^{\mathrm{b}}\end{array}$ & $\begin{array}{c}\mathrm{HBr} \\
\mathrm{pK}_{\mathrm{a}}{ }^{\mathrm{MeCN}}=5.4^{\mathrm{b}}\end{array}$ \\
\hline 1 & 27.4 & $2.3 / 5.2^{\mathrm{c}}$ & $4.1 / 6.5^{\mathrm{c}}$ \\
\hline 2 & 19.8 & $0.5 / 7.3^{\mathrm{c}}$ & 13.0 \\
\hline 3 & 17.5 & 14.8 & 21.0 \\
\hline 4 & 23.8 & 21.0 & 25.3 \\
\hline
\end{tabular}

a An estimated value is taken from [44]; ${ }^{\mathrm{b}}$ Experimental values are taken from [45]; ${ }^{\mathrm{c}}$ The values for $\mathrm{TSn}^{\mathrm{PT}}{ }_{\mathrm{HX}} / \mathrm{TSn}^{\mathrm{ELIM}}{ }_{\mathrm{HX}}$ are given.

In the case of $\mathrm{HCl}$ (Figure 2, Figure S3) and $\mathrm{HBr}$ (Figures S4 and S5), the reaction featured two distinct TS's, i.e., for proton transfer $\left(\mathbf{T S n}^{\mathbf{P T}}\right)$ and $\mathrm{H}_{2}$ elimination $\left(\mathbf{T S n}{ }^{\mathrm{ELIM}}\right)$. The activation barriers of TSn $^{\mathrm{PT}}$ were small $(0.5-4.1 \mathrm{kcal} / \mathrm{mol}$ in the case of M06/6-311++G(d,p) and $3.2-7.1 \mathrm{kcal} / \mathrm{mol}$ in the case of $w B 97 X D / 6-311++G(\mathrm{~d}, \mathrm{p})$, see Figures S3 and S5), comparable to the first step of the gas phase reaction between $\mathrm{BH}_{4}{ }^{-}$and $\mathrm{CF}_{3} \mathrm{OH}(4.2 \mathrm{kcal} / \mathrm{mol})$ [21]. The case of $\mathrm{HCl}$ demonstrates how the energy of the complex with molecular hydrogen $\mathrm{Cl}^{-}$ $\left[\left(\eta^{2}-\mathrm{H}_{2}\right) \mathrm{BH}_{(3-\mathrm{x})} \mathrm{Cl}_{\mathrm{x}}\right](\mathrm{x}=0-3)$ changes during the reaction (Figure 2). At the first step $(\mathrm{n}=1$, Figure 2), $\eta^{2}-\mathrm{H}_{2}$ complex was a local minimum with $\Delta \mathrm{G}^{\circ} \mathrm{MeCN}=3.8 \mathrm{kcal} / \mathrm{mol}$. Then, at the second step $(\mathrm{n}=2$, Figure 2$)$, the energy rose, and it became a quasi-stationary intermediate at $11.7 \mathrm{kcal} / \mathrm{mol}$. Over the next two steps, it disappeared, and the transition state became concerted. These changes were not surprising; during the reaction, as $\mathrm{H}^{-}$was replaced by $\mathrm{X}^{-}(\mathrm{X}=\mathrm{Cl}, \mathrm{Br})$, the electron deficiency of the boron atom increased and, on the other hand, $\pi$-back-donation from occupied $2 p_{\pi}(X)$ orbital to vacant $2 p_{\pi}(B)$ orbital decreased. This led to an increase in the $\mathrm{HDA}_{\mathrm{MeCN}}$ of $\mathrm{B}-\mathrm{H}$ bond in substitution products, and hence to a decrease of the B-H bond's capability to hydride transfer. As a result, the hydrohalogenation process became concerted, and the activation barriers $\left(\Delta \mathrm{G}^{\circ} \mathrm{MeCN}^{\ddagger(\mathrm{span})}\right.$, Tables S5 and S6) increased (from 9.1 to $26.1 \mathrm{kcal} / \mathrm{mol}$ for $\mathrm{HCl}$ and from 14.6 to $29.5 \mathrm{kcal} / \mathrm{mol}$ for $\mathrm{HBr}$; and, in the case of wB97XD/6-311++G(d,p), from 10.1 to $28.6 \mathrm{kcal} / \mathrm{mol}$ for $\mathrm{HCl}$ and from 13.1 to $29.2 \mathrm{kcal} / \mathrm{mol}$ for $\mathrm{HBr}$ ). In addition, due to the high electrophilicity of boron atoms in chloro- and bromoborohydrides the propensity of $\mathrm{B}-\mathrm{H}$ bonds to proton and hydride transfer become comparable in magnitude $\left(\mathrm{PDA}^{\mathrm{MeCN}}=85.5\right.$ and $83.5 \mathrm{kcal} / \mathrm{mol} \mathrm{vs}$. $\mathrm{HDA}^{\mathrm{MeCN}}=73.0$ and $77.6 \mathrm{kcal} / \mathrm{mol}$ for $\mathrm{Li}\left[\mathrm{BHCl}_{3}\right]$ and $\mathrm{Li}\left[\mathrm{BHBr}_{3}\right]$ respectively).

Thus, the value of the activation energy was influenced by two factors: the strength of the acid, which significantly lowered the activation barrier by increasing the polarization of the B-H bond in DHB complexes, and the ability of the occupied $2 \mathrm{p}_{\pi}(\mathrm{X})$ orbital to effectively back-donate to vacant $2 \mathrm{p}_{\pi}(\mathrm{B})$. In view of both of these factors, hydrogen chloride was the golden reactant, and the observed activation energy values the reaction of $\mathrm{BH}_{4}{ }^{-}$with $\mathrm{HCl}$ were the lowest (Table 1). Taking into account these findings, the DFT investigation of the reactivity of $\left[\mathrm{B}_{6} \mathrm{H}_{6}\right]^{2-}$ in electrophile-induced nucleophilic substitution (EINS) was carried out only on an example of the interaction with $\mathrm{HCl}$ in acetonitrile (MeCN).

\subsection{Interaction of Hexahydro-Closo-Hexaborate Dianion with Hydrogen Chloride}

Polyhedral closo-boranes are characterized by rather high values of hydride donor ability (e.g., $\mathrm{HDA}_{\mathrm{MeCN}}=71.9 \mathrm{kcal} / \mathrm{mol}$ for $\left[\mathrm{B}_{6} \mathrm{H}_{6}\right]^{2-}$ and $79.6 \mathrm{kcal} / \mathrm{mol}$ for $\left[\mathrm{B}_{12} \mathrm{H}_{12}\right]^{2-}$ ), which indicates the weak ability of the nonactivated B-H bond in closo-boranes to hydride transfer [29]. It is not surprising, therefore, that the most common method of functionalization of polyhedral boron hydrides follows the mechanism of electrophile-induced nucleophilic substitution (EINS) (Scheme 1). At the first stage, an electrophile promoter $\mathrm{E}^{+}$is attached to the boron skeleton of a closo-borane. Then, the hydride bound to the electrophile is eliminated, with the formation of a quasi-borinium cation [53]. Finally, at the last stage, the nucleophile attachment occurs. At that point, if $\mathrm{E}^{+}=\mathrm{H}^{+}$, the protonated closoborane intermediate should convert into a $\eta^{2}-\mathrm{H}_{2}$ complex-which is generally unstable and readily loses $\mathrm{H}_{2}$, making the addition of the nucleophile easier. 


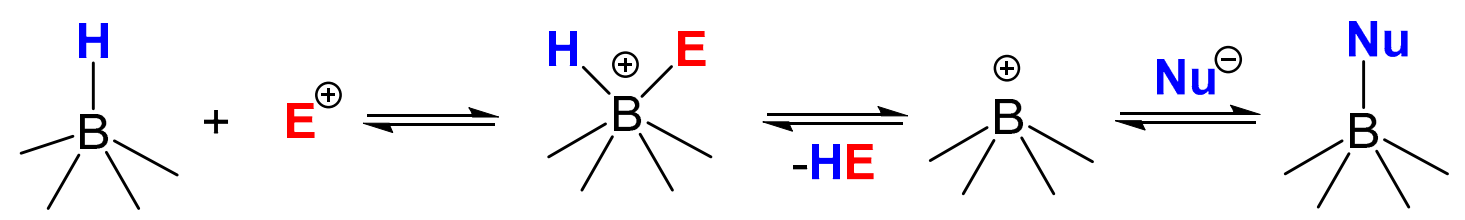

Scheme 1. Mechanism of electrophile-induced nucleophilic substitution (EINS).

However, the main problems of functionalization of polyhedral boron hydrides through this mechanism are low specificity of nucleophilic substitution and difficulties in controlling the degree of substitution [54]. The reactivity of the remaining BH groups in nucleophilic substitution products can be estimated using the hydride donor ability $\left(\mathrm{HDA}_{\mathrm{MeCN}}\right)$. Thus, as discussed in this section, applying this approach, we explored the EINS successive mechanism on the example of the reaction of $\left[\mathrm{B}_{6} \mathrm{H}_{6}\right]^{2-}$ with $\mathrm{HCl}$ in acetonitrile.

The $\left[\mathrm{B}_{6} \mathrm{H}_{6}\right]^{2-}$ is the smallest stable closo-borane dianion $[29,55,56]$, where the bulk of electron density is located on the boron atoms of the octahedral skeleton. The high nucleophilicity of boron atoms [57] in $\left[\mathrm{B}_{6} \mathrm{H}_{6}\right]^{2-}$ leads to its easy protonation. However, an attempt to isolate protonated species from $\mathrm{Cs}_{2}\left[\mathrm{~B}_{6} \mathrm{H}_{6}\right]$ in acidic aqueous solutions was unsuccessful due to irreversible hydrolysis of $\left[\mathrm{B}_{6} \mathrm{H}_{6}\right]^{2-}$ to borates and boric acid under these conditions [58]. Nevertheless, $\left[{ }^{\mathrm{fac}} \mathrm{HB}_{6} \mathrm{H}_{6}\right]^{-}\left(\mathrm{pK}_{\mathrm{a}} \mathrm{H} 2 \mathrm{O}=7.00\right)[18,59]$, in the form of $\mathrm{Bu}_{4} \mathrm{~N}^{+}$ and $\mathrm{Ph}_{4} \mathrm{P}^{+}$salts, was isolated from weakly acidic $(\mathrm{pH}=4.5) \mathrm{H}_{2} \mathrm{O}-\mathrm{HCl}$ solutions and characterized by X-ray diffraction $[58,60]$. It was found that the ${ }^{\text {fac }} \mathrm{H}^{+}$proton was located above the $\mathrm{B}_{3}$ triangle facets of the octahedron and coordinated through the $4 \mathrm{c}-3 \mathrm{e}$ bond $[18,58,60]$. The tendency of $\left[\mathrm{B}_{6} \mathrm{H}_{6}\right]^{2-}$ to hydrolyze in an acidic environment can be explained by the instability of the hypothetical doubly-protonated $\mathrm{B}_{6} \mathrm{H}_{8}$ closo-borane $[18,61,62]$. However, $\left[\mathrm{B}_{6} \mathrm{H}_{6}\right]^{2-}$ could be stable in acidic solutions if the protonation were stopped at the stage of [fac $\left.\mathrm{HB}_{6} \mathrm{H}_{6}\right]^{-}$formation [61].

It should be noted that the mechanisms of $\left[\mathrm{B}_{6} \mathrm{H}_{6}\right]^{2-}$ consecutive halogenation remain practically unexplored. Only the addition of the second halogen to $\left[\mathrm{B}_{6} \mathrm{H}_{5} \mathrm{X}\right]^{2-}$ in the presence of $\mathrm{X}_{2}$ and $\mathrm{H}_{2} \mathrm{O}(\mathrm{X}=\mathrm{Cl}, \mathrm{Br})$ has been explored by DFT, which proceeds with the partial opening of the boron cluster [17].

Thus, herein, we focused on the investigation of the EINS successive mechanism, simulated on the example of a model reaction in acetonitrile $(\mathrm{MeCN})$ at DFT/M06/6$311++G(d, p)$ (Figure 4) and wB97XD/6-311++G(d,p) (Figure S7, Table S12) theory levels. It was found that the reaction of $\left[\mathrm{B}_{6} \mathrm{H}_{6}\right]^{2-}$ with $\mathrm{HCl}$ proceeded via preliminary formation of hydrogen-bonded complex on $\mathrm{B}_{3}$ triangle facets $\left(\mathbf{I N T n}{ }^{\mathrm{HB}}\right.$ ) in three stages (Figure 5). These stages were: (1) protonation of the closo-borane cluster $\left(\mathbf{T S n}^{\mathrm{PT}}\right)$ on one of the $\mathrm{B}_{3}$ triangle facets with the formation of protonated form $\mathrm{Cl}^{-}\left[{ }^{\mathrm{fac}} \mathrm{HB}_{6} \mathrm{H}_{(6-\mathrm{x})} \mathrm{Cl}_{\mathrm{x}}\right]^{-}$ $(\mathrm{x}=0-5)\left(\mathbf{I N T} \mathbf{n}^{\mathrm{PT}}\right)$; (2) structural isomerization with $\mathrm{H}^{+}$migration from $\mathrm{B}_{3}$ triangle facet to $\mathrm{B}$ apex ( $\mathbf{T S n}^{\text {ISOfac-apx }}$ ) with the formation of complexes with molecular hydrogen $\mathrm{Cl}^{-}$ $\left[\left(\eta^{2}-\mathrm{H}_{2}\right) \mathrm{B}_{6} \mathrm{H}_{(5-x)} \mathrm{Cl}_{x}\right]^{-}\left(\eta^{2}-\mathrm{H}_{2}\right.$-intermediate, INTn $\left.{ }^{\mathbf{H} 2}\right)$; and (3) $\mathrm{H}_{2}$ elimination followed by frontal nucleophilic attack on boron atoms by $\mathrm{Cl}^{-}\left(\mathbf{T S n}^{\mathrm{ELIM}}\right)$, which is the last-and ratelimiting - stage. As can be seen (Figure 4), the activation barrier of the protonation stage was very low for all dianions $\left[\mathrm{B}_{6} \mathrm{H}_{(6-\mathrm{x})} \mathrm{Cl}_{\mathrm{x}}\right]^{2-}(\mathrm{x}=0-5)\left(\Delta \mathrm{G}^{\ddagger}\right.$ of $\left.\mathbf{T S n}^{\mathrm{PT}}=2.5-10.7 \mathrm{kcal} / \mathrm{mol}\right)$; therefore, it did not matter which type of acid we chose to use for protonation. The only important limitation is that the $\mathrm{pK}_{\mathrm{a}}$ of the proton donor used should be higher than the $\mathrm{pK}_{\mathrm{a}}$ of $\mathrm{Cl}^{-}\left[{ }^{\mathrm{fac}} \mathrm{HB}_{6} \mathrm{H}_{(6-\mathrm{x})} \mathrm{Cl}_{\mathrm{x}}\right]^{-}(\mathrm{x}=0-5)$. After protonation, the reaction turned into a classical one-isomerization of $\mathrm{Cl}^{-}\left[{ }^{\mathrm{fac}} \mathrm{HB}_{6} \mathrm{H}_{(6-\mathrm{x})} \mathrm{Cl}_{\mathrm{x}}\right]^{-}$to $\mathrm{Cl}^{-}\left[\left(\eta^{2}-\mathrm{H}_{2}\right) \mathrm{B}_{6} \mathrm{H}_{(5-\mathrm{x})} \mathrm{Cl}_{\mathrm{x}}\right]^{-}(\mathrm{x}=0-5)$ ( $\mathrm{TSn}^{\text {ISOfac-apx }}$ ) and $\mathrm{H}_{2}$ elimination ( $\mathrm{TSn}^{\mathrm{ELIM}}$ ) in the presence of a nucleophile $\left(\mathrm{Cl}^{-}\right)$. As can be seen from the reaction profile (Figure 4), the $\mathrm{H}_{2}$ elimination was the rate-limiting stage and, therefore, the activation barrier of this stage and the selectivity of this process should be determined by the metastable $\eta^{2}-\mathrm{H}_{2}$ reaction intermediate. 
M06/6-311++G(d,p)

$$
\begin{aligned}
-n & =1, x=0 \\
-n & =2, x=1 \\
-n & =3, x=2 \\
-n & =4, x=3 \\
-n & =5, x=4 \\
-n & =6, x=5
\end{aligned}
$$

\section{$\Delta \mathrm{G}^{\mathbf{o}}{ }_{\mathrm{MeCN}}$ in $\mathrm{kcal} / \mathrm{mol}, 298 \mathrm{~K}$}

TSn ${ }^{\text {ELIM }} \quad 44.9$

\section{7}

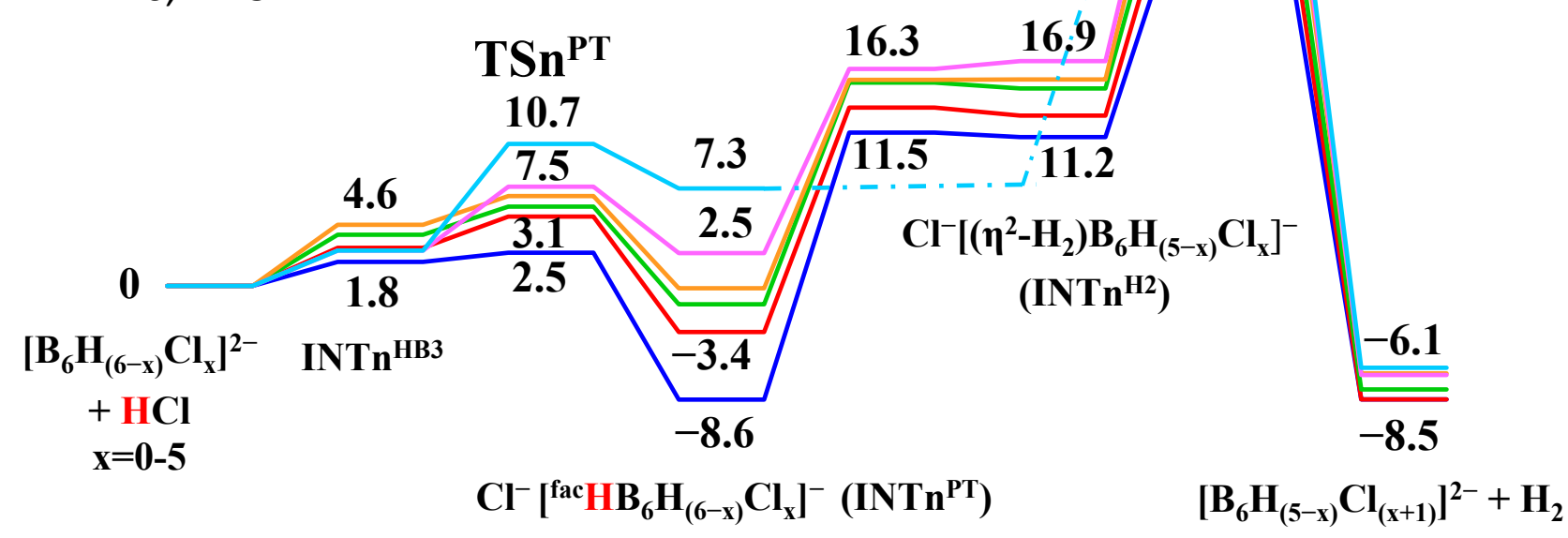

Figure 4. M06-calculated energy profile $\left(\Delta \mathrm{G}^{\circ} \mathrm{MeCN}\right.$ in $\left.\mathrm{kcal} / \mathrm{mol}\right)$ of halogenation of $\left[\mathrm{B}_{6} \mathrm{H}_{(6-x)} \mathrm{Cl}_{\mathrm{x}}\right]^{2-}(\mathrm{x}=0-5)$ by $\mathrm{HCl}$ for the pathway: $\left[\mathrm{B}_{6} \mathrm{H}_{6}\right]^{2-} \rightarrow 1-\left[\mathrm{B}_{6} \mathrm{H}_{5} \mathrm{Cl}\right]^{2-} \rightarrow 1,2-\left[\mathrm{B}_{6} \mathrm{H}_{4} \mathrm{Cl}_{2}\right]^{2-}($ cis $) \rightarrow 1,2,3-\left[\mathrm{B}_{6} \mathrm{H}_{3} \mathrm{Cl}_{3}\right]^{2-}($ fac $) \rightarrow 1,2,3,4-\left[\mathrm{B}_{6} \mathrm{H}_{2} \mathrm{Cl}_{4}\right]^{2-}($ cis $) \rightarrow$ $1,2,3,4,6-\left[\mathrm{B}_{6} \mathrm{HCl}_{5}\right]^{2-}$.

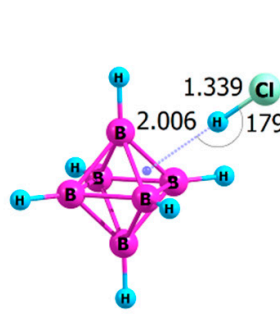

INT1 ${ }^{\mathrm{HB} 3}$

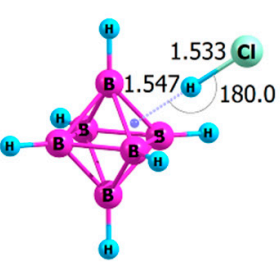

TS1PT

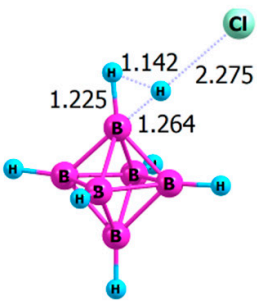

$\mathrm{TS}^{\mathrm{ISO}_{\text {fac-apx }}}$

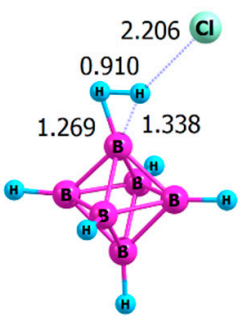

INT1 ${ }^{\mathrm{H} 2}$

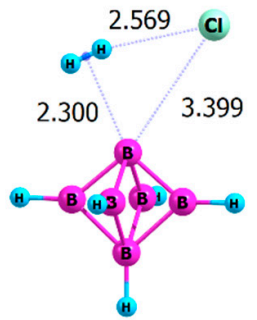

TS1ELIM

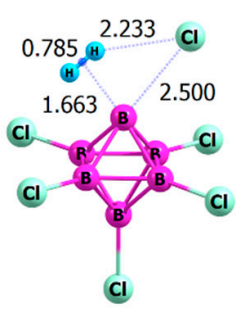

TS6 $6^{\text {CONC }}$

Figure 5. M06-optimized transition states of reaction $\left[\mathrm{B}_{6} \mathrm{H}_{6}\right]^{2-}$ with $\mathrm{HCl}$. The $\mathrm{r}_{(\mathrm{X} \cdots \mathrm{Y})}$ bond distances shown are in $\AA$.

The first reaction intermediate was the hydrogen-bonded complex (INTn ${ }^{\mathrm{HB} 3}$ ) with $\mathrm{HCl}$ coordination on $\pi$-density of the $\mathrm{B}_{3}$ triangle facet of the $\left[\mathrm{B}_{6} \mathrm{H}_{(6-x)} \mathrm{Cl}_{\mathrm{x}}\right]^{2-}(\mathrm{x}=0-5)$ polyhedron [63]. It should be noted that the electron density of hydride atoms in $\left[\mathrm{B}_{6} \mathrm{H}_{6}\right]^{2-}$ is much lower than the electron density of $\mathrm{B}_{3}$ triangle facets; therefore, in contrast to $\mathrm{BH}_{4}{ }^{-}[34,35,64],\left[\mathrm{B}_{10} \mathrm{H}_{10}\right]^{2-}[49,65]$, and $\left[\mathrm{B}_{12} \mathrm{H}_{12}\right]^{2-}[65]$, the complexation of proton donors occurred exclusively on $\mathrm{B}_{3}$ triangle facets $[66,67]$. Upon the successive replacement of $\mathrm{H}^{-}$ with $\mathrm{Cl}^{-}$in the closo-borane structure, gradual increases in the electron deficiency of the skeleton of closo-borane and the electrophilicity of boron atoms were observed. As the result, the values of hydride donor ability $\left(\mathrm{HDA}_{\mathrm{MeCN}}\right.$, Table S8) increase, whereas the values of proton donor ability $\left(\mathrm{PDA}_{\mathrm{MeCN}}\right)$ decrease (Table S8). This indicates a change in the character of boron atoms in closo-borane from nucleophilic to highly electrophilic and an increase of the Lewis acidity of the corresponding quasi-borinium cations $\left[\mathrm{B}_{6} \mathrm{H}_{(5-\mathrm{x})} \mathrm{Cl}_{\mathrm{x}}\right]^{-}$formed as the result of $\mathrm{H}^{-}$transfer from $\left[\mathrm{B}_{6} \mathrm{H}_{(6-x)} \mathrm{Cl}_{\mathrm{x}}\right]^{2-}$. Thus, for example, for $\left[\mathrm{B}_{6} \mathrm{HCl}_{5}\right]^{2-}$, the proton transfer becomes more favorable than hydride transfer, which correlates with better 
hydrolytic stability of tetra- and penta-halogen derivatives of $\left[\mathrm{B}_{6} \mathrm{H}_{6}\right]^{2-}$ in acidic aqueous solutions and increased acidity of protonated monosubstituted halogenated derivatives $\left.{ }^{\text {fac }} \mathrm{HB}_{6} \mathrm{H}_{5} \mathrm{X}\right]^{-}\left(\mathrm{pK}_{\mathrm{a}}{ }^{\mathrm{H} 2 \mathrm{O}}\right.$ for $\mathrm{X}=\mathrm{Cl}, \mathrm{Br}$, I were $5.35,5.00$ and 4.65, respectively; in comparison, $\mathrm{pK}_{\mathrm{a}}{ }^{\mathrm{H} 2 \mathrm{O}}=7.00$ for $\left.\left.{ }^{\mathrm{fac}} \mathrm{HB}_{6} \mathrm{H}_{6}\right]^{-}\right)[42,43]$. The study of the electronic structure of polyhedral closo-borane dianions $\left[\mathrm{B}_{6} \mathrm{H}_{(6-\mathrm{x})} \mathrm{Cl}_{\mathrm{x}}\right]^{2-}(\mathrm{x}=1-5)$ utilizing the NBO method showed that, as the substitution proceeded, the polarization of the hydrogen atom occurred. which It became less hydridic (the charge of the hydrogen atom varied from -0.027 to 0.002 ). These changes were manifested in a weakening of the hydrogen bond (decrease of $\mathrm{E}_{\mathrm{H} \cdots \mathrm{B}(\mathrm{B} 2)}$ and $\mathrm{E}^{2}$, Table S8), an elongation of $\mathrm{H} \cdots \mathrm{B}_{3}$ distances (Table S9), and a decrease in the enthalpy of $\mathrm{H} \cdots \mathrm{B}_{3}\left(\right.$ INTn $^{\mathrm{HB} 3}$ ) complexes' formation (Table S9).

The energy barrier of the proton transfer reaction was very low $(2.5-7.5 \mathrm{kcal} / \mathrm{mol})$; thus, in the presence of acids, the protonated reaction intermediates $\mathrm{Cl}^{-}\left[{ }^{\mathrm{fac}} \mathrm{HB}_{6} \mathrm{H}_{(6-\mathrm{x})} \mathrm{Cl}_{\mathrm{x}}\right]^{-}$ $(\mathrm{x}=0-5)\left(\mathbf{I N T}{ }^{\mathrm{PT}}\right)$ were immediately formed (Figure S3). At the early stages of the reaction, these were characterized by significant energy formation $\left(\Delta \mathrm{G}_{f}{ }^{\circ} \mathrm{MeCN}\right.$ from $-8.5 \mathrm{kcal} / \mathrm{mol}$ for $\left.\mathrm{Cl}^{-}{ }^{\text {fac }} \mathrm{HB}_{6} \mathrm{H}_{6}\right]^{-}$to $-0.4 \mathrm{kcal} / \mathrm{mol}$ for $\mathrm{Cl}^{-}\left[{ }^{\mathrm{fac}} \mathrm{HB}_{6} \mathrm{H}_{2} \mathrm{Cl}_{4}\right]^{-}$). Previously, instability of $\left[\mathrm{B}_{6} \mathrm{H}_{6}\right]^{2-}$ in acidic water solutions was explained by possible further protonation and formation of doubly protonated products $[18,61,62]$. The calculated energy

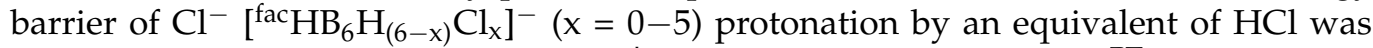
higher by $8.8-16.0 \mathrm{kcal} / \mathrm{mol}\left(\Delta \mathrm{G}^{\circ} \mathrm{MeCN}^{\ddagger}=9.5-23.0 \mathrm{kcal} / \mathrm{mol}\right.$ for $\mathbf{T S n}^{\mathrm{PT}}{ }_{\text {2nd }}$, Table S10 $)$ than protonation of $\left[\mathrm{B}_{6} \mathrm{H}_{(6-\mathrm{x})} \mathrm{Cl}_{\mathrm{x}}\right]^{2-}$, and its energy increased over the course of halogenation. It should be noted that the formation of doubly-protonated intermediates $\mathrm{Cl}^{-}\left({ }^{\mathrm{fac}} \mathrm{HB}_{6} \mathrm{H}_{(6-\mathrm{x})} \mathrm{Cl}_{\mathrm{x}}{ }^{\mathrm{fac}} \mathrm{H}\right) \cdot \mathrm{Cl}^{-}(\mathrm{x}=0-5)$ is endoergic $\left(\Delta \mathrm{G}_{f}{ }^{\circ} \mathrm{MeCN}\right.$ values ranged from $9.7 \mathrm{kcal} / \mathrm{mol}$ for $\mathrm{Cl}^{-}\left({ }^{\text {fac }} \mathrm{H}_{2} \mathrm{~B}_{6} \mathrm{H}_{6}{ }^{\text {fac }} \mathrm{H}\right) \cdot \mathrm{Cl}^{-}$to $29.3 \mathrm{kcal} / \mathrm{mol}$ for $\left.\mathrm{Cl}^{-}\left({ }^{\mathrm{fac}} \mathrm{HB}_{6} \mathrm{HCl}_{5}{ }^{\mathrm{fac}} \mathrm{H}\right) \cdot \mathrm{Cl}^{-}\right)$. The activation energy of the reverse reaction $\left(\mathbf{T S}^{{ }^{\mathrm{PT}}}{ }_{2 n d(r e v)}\right.$, Table S10) was less than $3.8 \mathrm{kcal} / \mathrm{mol}$. All this indicated that it was possible to stop the protonation reaction at the stage of the monoprotonated product, in the presence of equimolar amounts of the proton donor.

It should be noted that the structure of $\left[{ }^{\mathrm{fac}} \mathrm{HB}_{6} \mathrm{H}_{(6-\mathrm{x})} \mathrm{Cl}_{\mathrm{x}}\right]^{-}(\mathrm{x}=0-5)$ anions is nonrigid and, in solutions, they are prone to the fluctuation of ${ }^{\text {fac }} \mathrm{H}^{+}$proton between octahedral edges [18]. During $\left[\mathrm{B}_{6} \mathrm{H}_{6}\right]^{2-}$ halogenation, the $\mathrm{Cl}^{-}\left[{ }^{-\mathrm{fac}^{2}} \mathrm{HB}_{6} \mathrm{H}_{(6-\mathrm{x})} \mathrm{Cl}_{\mathrm{x}}\right]^{-}$to $\mathrm{Cl}^{-}$ $\left[\left(\eta^{2}-\mathrm{H}_{2}\right) \mathrm{B}_{6} \mathrm{H}_{(5-x)} \mathrm{Cl}_{\mathrm{x}}\right]^{-}(\mathrm{x}=0-5)$ isomerization (TSn ${ }^{\text {ISOfac-apx }}$, Figure 5) was observed, with energy barriers decreasing from $20.1 \mathrm{kcal} / \mathrm{mol}$ at the first step to $13.8 \mathrm{kcal} / \mathrm{mol}$ at the sixth (Table 2) - correlating with an increase in the electrophilic nature of boron atoms during halogenation.

There was also a competitive $\mathrm{Cl}^{-}\left[{ }^{\mathrm{fac}} \mathrm{HB}_{6} \mathrm{H}_{(6-\mathrm{x})} \mathrm{Cl}_{\mathrm{x}}\right]^{-}$to $\left[\mathrm{B}_{6} \mathrm{H}_{(6-\mathrm{x})} \mathrm{Cl}_{\mathrm{x}} \mathrm{H}^{\mathrm{fac} *}\right]^{-} \cdot \mathrm{Cl}^{-}$ $(\mathrm{x}=0-5)$ isomerization process ( $\mathbf{T S n}^{\text {ISOfac-fac }}$, Table S9), which corresponded to ${ }^{\text {fac }} \mathrm{H} / \mathrm{H}^{\text {term }}$ exchange. As is known, $\left[\mathrm{B}_{6} \mathrm{H}_{6}\right]^{2-}$ can be completely deuterated in $\mathrm{D}_{2} \mathrm{O}$ solution-and activation energy of the deuteration $(18.0 \mathrm{kcal} / \mathrm{mol})[18,59]$ was close to the calculated activation energy of $17.3 \mathrm{kcal} / \mathrm{mol}$ for the $\mathbf{T S n}{ }^{\text {ISOfac-fac* }}$ isomerization of $\left.{ }^{\text {fac }}{ }^{\text {HB }} \mathrm{HB}_{6} \mathrm{H}_{6}\right]^{-}$. Thus, the exchange between ${ }^{\text {fac }} \mathrm{H}$ and $\mathrm{H}^{\text {term }}$ ligands (TSn ${ }^{\text {ISOfac-fac }}{ }^{*}$, Scheme 2) featuring a lower barrier than TSn ${ }^{\text {ELIM }}$ did not result in $\mathrm{H}_{2}$ elimination-which requires $\eta^{2}-\mathrm{H}_{2}$ complex formation.

A third reaction intermediate, which is $\mathrm{Cl}^{-}\left[\left(\eta^{2}-\mathrm{H}_{2}\right) \mathrm{B}_{6} \mathrm{H}_{(6-x)} \mathrm{Cl}_{x}\right]^{-}$complex $\left(\mathbf{I N T n}^{\mathbf{H} 2}\right)$ (Table S10) was observed for almost all stages of reaction of $\left[\mathrm{B}_{6} \mathrm{H}_{(6-x)} \mathrm{Cl}_{\mathrm{x}}\right]^{2-}(\mathrm{x}=0-5)$ with $\mathrm{HCl}$ (except $\left[\mathrm{B}_{6} \mathrm{HCl}_{5}\right]^{2-}$ ). This complex is a key intermediate of the process which determines the selectivity of nucleophilic substitution, since stabilization of $\mathrm{H}_{2}$ at one of the vertices of the closo-borane octahedron determines the position of nucleophilic substitution at this vertex. Notably, this complex was not revealed at the gas phase calculations of $\mathrm{Cl}^{-}$ $\left.{ }^{\text {fac }} \mathrm{HB}_{6} \mathrm{H}_{6}\right]^{-}$[68]. Similarly to the $\mathrm{Cl}^{-}\left[\left(\eta^{2}-\mathrm{H}_{2}\right) \mathrm{B}_{10} \mathrm{H}_{9}\right]^{-}$[49] it could be stabilized only in the presence of $\mathrm{HX}$ acid residue $\mathrm{X}^{-}$. 
Table 2. Hydride donor ability $\left(\mathrm{HDA}_{\mathrm{MeCN}}\right)$ of the $\mathrm{B}-\mathrm{H}$ center in $\left[\mathrm{B}_{6} \mathrm{H}_{(6-\mathrm{x})} \mathrm{Cl}_{\mathrm{x}}\right]^{2-}(\mathrm{x}=0-5)$, involved in halogenation reactions, and activation barriers $\left(\Delta \mathrm{G}^{\circ} \mathrm{MeCN}^{\ddagger}\right.$, in $\left.\mathrm{kcal} / \mathrm{mol}\right)$ for TSs for the reaction of $\left[\mathrm{B}_{6} \mathrm{H}_{6}\right]^{2-}$ with $\mathrm{HCl}\left(\mathrm{pK}_{\mathrm{a}} \mathrm{MeCN}_{=} 10.3\right.$ [42]) in MeCN, computed at the M06/6-311++G(d,p) theory level.

\begin{tabular}{|c|c|c|c|c|c|c|}
\hline n & $\mathrm{N}$ of Position & $\mathrm{HDA}_{\mathrm{MeCN}{ }^{\prime \mathbf{a}}}$ & $\begin{array}{l}\Delta \mathrm{G}^{\circ} \mathrm{MeCN}^{\ddagger} \\
\left(\mathrm{TSn}^{\mathrm{PT}}\right)^{\mathrm{a}}\end{array}$ & $\begin{array}{c}\Delta \mathrm{G}^{\circ} \mathrm{MeCN}^{\ddagger} \\
\left(\mathrm{TSn}^{\text {ISOfac-apx }}\right)^{\mathrm{b}}\end{array}$ & $\begin{array}{l}\Delta \mathrm{G}^{\circ} \mathrm{MeCN}^{\ddagger} \\
\left(\mathrm{TSn}^{\mathrm{ELIM}}\right)^{\mathrm{c}}\end{array}$ & $\Delta \mathrm{G}^{\circ} \mathrm{MeCN}^{\ddagger(\text { span }) \mathrm{d}}$ \\
\hline 1 & 1 & 71.9 & 0.7 & 20.1 & 19.6 & 39.3 \\
\hline \multirow{2}{*}{2} & 1,2 (cis) & 76.6 & 1.3 & 19.8 & 21.9 & 38.2 \\
\hline & 1,6 (trans) & 80.0 & 2.3 & 19.0 & 26.0 & 44.3 \\
\hline \multirow{3}{*}{3} & $1,2,3(\mathrm{fac})$ & 81.0 & 2.1 & 19.4 & 23.0 & 39.2 \\
\hline & $1,2,6$ (mer) & 84.7 & 2.2 & 17.9 & 26.0 & 41.5 \\
\hline & 1,6,2 (mer) & 81.1 & 3.6 & 16.7 & 23.4 & 40.2 \\
\hline \multirow{3}{*}{4} & $1,2,3,4(\mathrm{cis})$ & 88.6 & 2.1 & 17.4 & 26.6 & 42.3 \\
\hline & $1,6,2,3$ (cis) & 84.9 & 4.2 & 16.0 & 24.4 & 42.0 \\
\hline & $1,6,2,4$ (trans) & 88.6 & 3.9 & 15.0 & 26.4 & 40.2 \\
\hline \multirow{2}{*}{5} & $1,2,3,4,6$ & 92.5 & 4.8 & 13.8 & 26.8 & 43.7 \\
\hline & $1,6,2,4,3$ & 88.4 & 7.2 & \multicolumn{2}{|c|}{$37.4^{*}$} & 42.4 \\
\hline 6 & $1,2,3,4,6,5$ & 95.6 & 8.0 & \multicolumn{2}{|c|}{$37.6 *$} & 44.9 \\
\hline \multicolumn{7}{|c|}{ 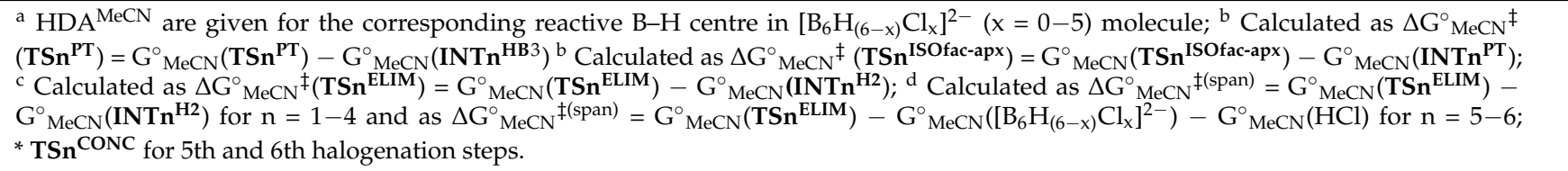 } \\
\hline
\end{tabular}
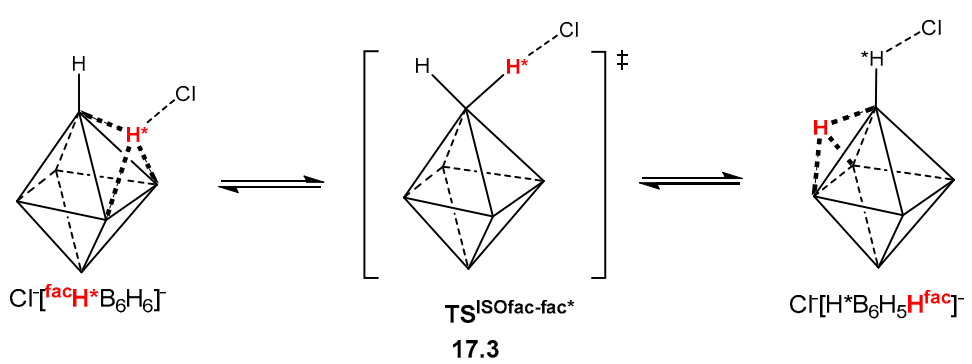

Scheme 2. The $\mathrm{H}^{\mathrm{fac}} / \mathrm{H}^{\mathrm{fac}}$ exchange mechanism in $\mathrm{Cl}^{-}\left[{ }^{\mathrm{fac}} \mathrm{H}^{*} \mathrm{~B}_{6} \mathrm{H}_{6}\right]^{-} . \Delta \mathrm{G}^{\circ} \mathrm{MeCN}^{\ddagger(\text { span })}$ shown in bold numbers are in $\mathrm{kcal} / \mathrm{mol}$.

As the halogenation of $\left[\mathrm{B}_{6} \mathrm{H}_{6}\right]^{2-}$ progressed, the formation energy of the $\mathrm{H}_{2}$ intermediate decreased, and $\mathrm{B}-\mathrm{H}$ and $\mathrm{Cl} \cdots \mathrm{H}$ bonds became stronger while $\mathrm{H} \cdots \mathrm{H}$ interaction weakened. This coincided with a trend toward an increase in the electrophilicity of the B-H bond and an increase in its acidity. Thus, the established regularities allowed for the use of the stabilization of $\mathrm{H}_{2}$ complex to control the process of nucleophilic substitution and lower the activation energy of this process.

The same trend was observed for the rate-limiting stage of $\mathrm{H}_{2}$ elimination, for which the energy barrier increased from 19.6 to $42.3 \mathrm{kcal} / \mathrm{mol}\left(\Delta \mathrm{G}^{\circ} \mathrm{MeCN}^{\ddagger}\left(\mathbf{T S n}^{\mathbf{P T}}\right)\right.$, shown in Table 2, and from 24.6 to $44.6 \mathrm{kcal} / \mathrm{mol}$ for wB97XD/6-311++G(d,p), shown in Table S12. It should be noted that nucleophilic substitution by $\mathrm{Cl}^{-}$and solvation contributed greatly to the stabilization of the transition state-which was noticeable, as the activation energies obtained were compared with gas-phase activation energies for $\mathrm{H}_{2}$ elimination from $\left[{ }^{\mathrm{fac}} \mathrm{HB}_{6} \mathrm{H}_{6}\right]^{-}(\Delta \mathrm{E}=45.9 \mathrm{kcal} / \mathrm{mol})[69]$.

In the reaction of $\left[\mathrm{B}_{6} \mathrm{H}_{6}\right]^{2-}$ with $\mathrm{HCl}$ there were three branch points at the second, third, and fourth steps (Scheme 3) of halogenation when several geometries of halogenated derivatives were possible (Table 2). However, the optimal reaction pathway (with the lowest activation energy of TSn ${ }^{\text {ELIM }}$ at 2 nd and 3rd steps) was $\left[\mathrm{B}_{6} \mathrm{H}_{6}\right]^{2-} \rightarrow$ $1-\left[\mathrm{B}_{6} \mathrm{H}_{5} \mathrm{Cl}\right]^{2-} \rightarrow 1,2-\left[\mathrm{B}_{6} \mathrm{H}_{4} \mathrm{Cl}_{2}\right]^{2-}$ (cis) $\rightarrow 1,2,3-\left[\mathrm{B}_{6} \mathrm{H}_{3} \mathrm{Cl}_{3}\right]^{2-}($ fac $) \rightarrow 1,2,3,4-\left[\mathrm{B}_{6} \mathrm{H}_{2} \mathrm{Cl}_{4}\right]^{2-}$ (cis) 
$\rightarrow 1,2,3,4,6-\left[\mathrm{B}_{6} \mathrm{HCl}_{5}\right]^{2-}$. The existence of such branch points was found for 1-[ $\left[\mathrm{B}_{6} \mathrm{H}_{5} \mathrm{Cl}\right]^{2-}$, 1,2- $\left[\mathrm{B}_{6} \mathrm{H}_{4} \mathrm{Cl}_{2}\right]^{2-}$ (cis) and 1,2,6- $\left[\mathrm{B}_{6} \mathrm{H}_{3} \mathrm{Cl}_{3}\right]^{2-}$ (mer)-halogenated derivatives, in which there were two types of hydrides with different reactivities (as can be seen from $\mathrm{HDA}_{\mathrm{MeCN}}$ values, Table S8. As follows from Table 2, the smallest activation barrier corresponded to nucleophilic substitution at the boron atom, the bond of which was characterized by the smallest $\mathrm{HDA}_{\mathrm{MeCN}}$ value.

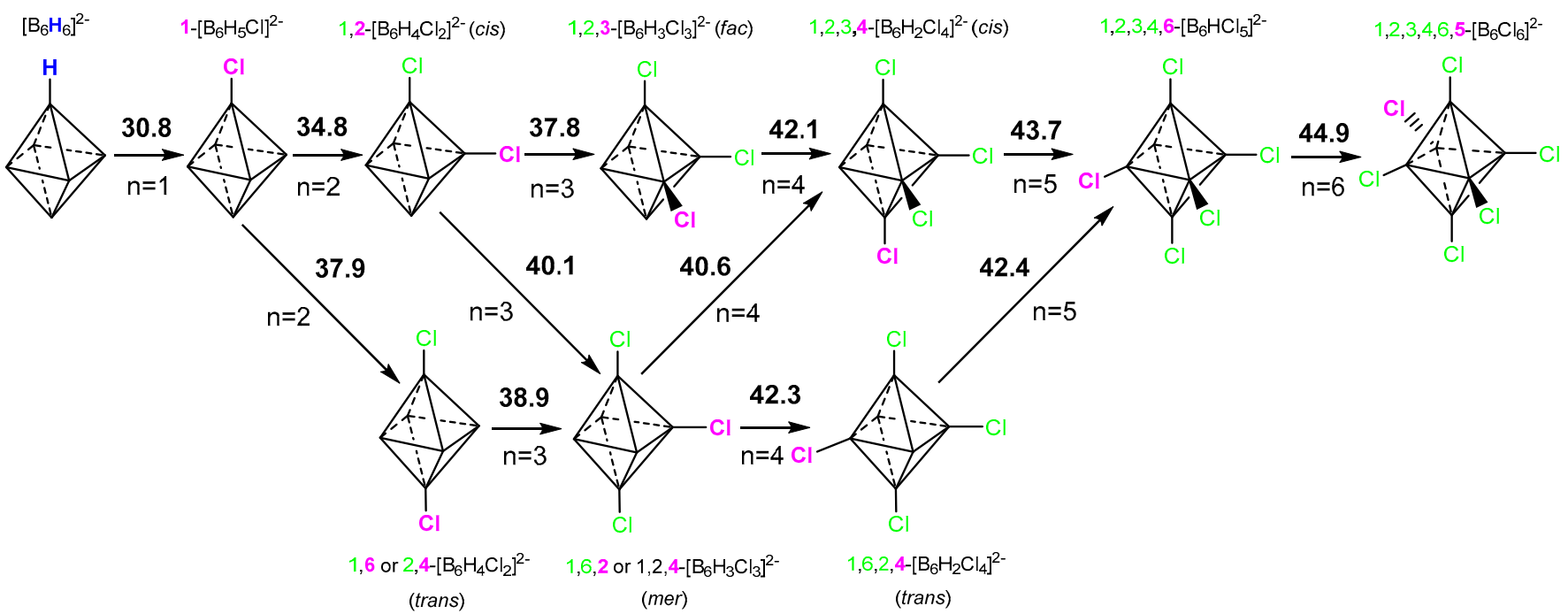

Scheme 3. Pathways of $\left[\mathrm{B}_{6} \mathrm{H}_{6}\right]^{2-}$ halogenation by $\mathrm{HCl}$. Free Gibbs energy span $\left(\Delta \mathrm{G}^{\circ} \mathrm{MeCN}^{\ddagger(s p a n)}\right.$ in kcal/mol) indicated as black bold numbers. $\mathrm{H}$-atoms are omitted for clarity. $\mathrm{Cl}$ atoms added at each particular step are shown in magenta.

It should be noted that under real conditions of halogenation of $\left[\mathrm{B}_{6} \mathrm{H}_{6}\right]^{2-}$ by $\mathrm{X}_{2}$ $(\mathrm{X}=\mathrm{Cl}, \mathrm{Br})$ in strong alkaline solutions, the reaction is nonspecific. In the second, third, and fourth steps of halogenation, the geometric isomers are formed in different ratios [18]. In this case, for $\mathrm{X}=\mathrm{I}$ pure geometric isomers, 1,6- $\left[\mathrm{B}_{6} \mathrm{H}_{4} \mathrm{I}_{2}\right]$ (trans), 1,6,2-[ $\left[\mathrm{B}_{6} \mathrm{H}_{3} \mathrm{I}_{3}\right]$ (mer) and 1,6,2,4-[ $\left[\mathrm{B}_{6} \mathrm{H}_{2} \mathrm{I}_{4}\right]$ (trans) were observed [70,71]. This was due to the less effective backdonation of larger-sized $2 p_{\pi}$ iodine orbitals to vacant $2 p_{\pi}(B)$. That, in turn, led to the favorable formation of the protonated complex $\left[{ }^{\mathrm{fac}} \mathrm{HB}_{6} \mathrm{H}_{5} \mathrm{X}\right]^{-}$, where ${ }^{\mathrm{fac}} \mathrm{H}^{+}$was located in antipodal-sphere of the $\left[\mathrm{B}_{6} \mathrm{H}_{6}\right]^{2-}$ octahedron $[18,72]$. Our calculations showed that, for $\left.{ }^{\text {fac }} \mathrm{HB}_{6} \mathrm{H}_{5} \mathrm{Cl}\right]^{-}$, the formation energy of the complex with ${ }^{\mathrm{fac}} \mathrm{H}^{+}$in the ipso-sphere of the $\left[\mathrm{B}_{6} \mathrm{H}_{6}\right]^{2-}$ octahedron was higher than that of the complex with ${ }^{\mathrm{fac}} \mathrm{H}^{+}$in the antipodal-sphere $\left(\Delta \Delta \mathrm{G}_{f}{ }^{\circ} \mathrm{MeCN}=3.0 \mathrm{kcal} / \mathrm{mol}\right)$. Moreover, ipso- $\left.{ }^{\mathrm{fac}} \mathrm{HB}_{6} \mathrm{H}_{5} \mathrm{Cl}\right]^{-}$was the active intermediate of $\left[\mathrm{B}_{6} \mathrm{H}_{5} \mathrm{Cl}\right]^{2-}$ halogenation to $1,2-\left[\mathrm{B}_{6} \mathrm{H}_{4} \mathrm{Cl}_{2}\right]^{2-}$ in our mechanism, as well as in that reported in [17]. Apparently, the larger electron-withdrawing effect of iodine in $\left[\mathrm{B}_{6} \mathrm{H}_{(6-\mathrm{x})} \mathrm{I}_{\mathrm{x}}\right]^{2-}$ $(\mathrm{x}=0-5)$ derivatives increases the difference between ipso/antipodal complexes.

Thus, the above-described reaction mechanism on the example of a model reaction of $\left[\mathrm{B}_{6} \mathrm{H}_{6}\right]^{2-}$ with $\mathrm{HCl}$ suggests the possibility of controlling the selectivity and the depth of the nucleophilic substitution processes by increasing the stabilization of the $\mathrm{H}_{2}$ complex on the desired position of the closo-borane cluster. Additionally, at the same time, $\mathrm{HDA}_{\mathrm{MeCN}}$ values for the $\mathrm{BH}$ groups would permit the carrying out of a nucleophilic substitution of $\mathrm{B}-\mathrm{H}$ bonds activated by Lewis acids $\left(\mathrm{BL}_{3}\right)$.

\section{Materials and Methods Computational Details}

In the present manuscript, the calculations were performed at the DFT/M06/6$311++G(d, p)$ level for comparison to the hydride donor ability (HDA) values of boron hydrides and other main group hydrides, as previously calculated by the same method $[28,30,73]$. Additionally, the values obtained can be used as a reference for assessing the effectiveness of the B-H bond activation by transition metals. In this regard, M06 is a more versatile 
method than M06-2X (generally recommended for thermochemistry calculations of main group elements) and can be used in cases where multi-reference systems are or might be involved, since it has been parametrized for both main group elements and transition metals [74]. The continuum solute model based on density (SMD) was used for nonspecific solvation, since this model was parametrized to work with the Minnesota functionals family (such as M06, M06-2X, etc.) and has proven to be effective for use in both charged and uncharged systems [75]. The nature of the stationary points on potential energy surfaces was proved by reoptimization of M06 geometries at wB97XD/6-311++G(d,p) level of theory.

All calculations were performed without symmetry constraints using the M06 hybrid functional [74] and wB97XD dispersion-corrected, range-separated hybrid functional [76] implemented in the Gaussian09 (Revision D.01) [77] software package, using $6-311++G(d, p)[78]$ basis set. Vibrational frequencies were calculated for all optimized complexes at the same level of theory to confirm a character of local minima on the potential energy surface. Visualization-optimized geometries were realized using the Chemcraft 1.8 graphical visualization program [79].

The inclusion of nonspecific solvent effects in the calculations was performed using the SMD method [75]. Acetonitrile ( $\mathrm{MeCN}, \varepsilon=35.7)$ was chosen as a solvent for optimization because of significant data, specific to $\mathrm{MeCN}$, already existed on reduction potentials, pKa values, and experimental values of hydride donor ability (HDA) of transition metal hydrides [24,25].

Calculations were carried out with an ultrafine integration grid and a very tight SCF option to improve the accuracy of the optimization procedure.

Hydride donor ability $\left(\mathrm{HDA}_{\mathrm{MeCN}}\right)$ and proton donor ability $\left(\mathrm{PDA}_{\mathrm{MeCN}}\right)$ of $\mathrm{E}-\mathrm{H}$ bond in $\mathrm{MeCN}$ were calculated as Gibbs free energy of hydride or proton transfer:

$$
\begin{aligned}
& \mathrm{HDA}_{\mathrm{MeCN}}=\Delta \mathrm{G}^{\circ}\left[\mathrm{H}^{-}\right]_{\mathrm{MeCN}}=\mathrm{G}^{\circ}{ }_{\mathrm{MeCN}}(\mathrm{E}+)+\mathrm{G}^{\circ}{ }_{\mathrm{MeCN}}(\mathrm{H}-)-\mathrm{G}^{\circ}{ }_{\mathrm{MeCN}}(\mathrm{E}-\mathrm{H}) \\
& \mathrm{PDA}_{\mathrm{MeCN}}=\Delta \mathrm{G}^{\circ}\left[\mathrm{H}^{+}\right]_{\mathrm{MeCN}}=\mathrm{G}^{\circ}{ }_{\mathrm{MeCN}}(\mathrm{E}-)+\mathrm{G}^{\circ}{ }_{\mathrm{MeCN}}(\mathrm{H}+)-\mathrm{G}^{\circ}{ }_{\mathrm{MeCN}}(\mathrm{E}-\mathrm{H})
\end{aligned}
$$

The value of $\mathrm{G}^{\circ} \mathrm{MeCN}\left(\mathrm{H}^{-}\right)=-413.9 \mathrm{kcal} / \mathrm{mol}$ was calculated by $\mathrm{M} 06 / 6-311++\mathrm{G}(\mathrm{d}, \mathrm{p})$ for the $\mathrm{H}^{-}$in $\mathrm{MeCN}$. The values of $\mathrm{G}^{\circ} \mathrm{MeCN}\left(\mathrm{H}^{+}\right)=-260.2 \mathrm{kcal} / \mathrm{mol}$ were taken from [80].

From data obtained during the geometry optimization for each molecule, the most stable configuration was chosen. To find the most stable configuration of cationic boranes, the terminal hydrogen atoms $\left(\mathrm{B}-\mathrm{H}_{\text {term }}\right)$ were torn off as $\mathrm{H}^{-}$or as $\mathrm{H}^{+}$from each vertex in optimized molecules. In the case of polyhedral closo-boranes, due to the rigid frame of the boron cluster [49,50], several quasi-borinium cations were observed, localized on vertices from which hydride was torn off.

The Wiberg bond indices [81] (WBI)—as a measure of electron distribution between two atoms [82] - and natural atomic charges were calculated using the natural-bond orbital (NBO) analysis [83] implemented in GAUSSIAN09 (Revision D.01) [77]. Topological analysis of the electron-density distribution function $\rho(\mathrm{r})$ was performed using the AIMALL [84] program package based on the wave function obtained by M06 calculations. The delocalization index (DI) [85-87], a measure of electrons that are shared or exchanged between two atoms or basins obtained from the integration of the Fermi hole density, was directly related to the bond order $[87,88]$. The $X-Y$ bond ellipticity, $\varepsilon_{X-Y}$, was defined as $\varepsilon=\left(\lambda_{1} / \lambda_{2}-1\right)$, where $\lambda_{1}$ and $\lambda_{2}$ are the negative eigen values of the Hessian of the electron density at the bond critical point, ordered such that $\lambda_{1}<\lambda_{2}<0$ [89-91]. The energies of $\mathrm{H} \cdots \mathrm{H}$ or $\mathrm{H} \cdots \mathrm{B}_{3}$ interactions were calculated as $\mathrm{E}_{\mathrm{H} \cdots \mathrm{H}}=0.5 \cdot \mathrm{V}(\mathrm{r})$, according to $[92,93]$.

\section{Conclusions}

The mechanism of the sequential halogenation of tetrahydroborate anions $\left[\mathrm{BH}_{4}\right]^{-}$ by hydrogen halides ( $\mathrm{HX}, \mathrm{X}=\mathrm{F}, \mathrm{Cl}, \mathrm{Br}$ ) and halogenation of hexahydro-closo-hexaborate dianions $\left[\mathrm{B}_{6} \mathrm{H}_{6}\right]^{2-}$ was established by ab initio DFT calculations $(\mathrm{M} 06 / 6-311++\mathrm{G}(\mathrm{d}, \mathrm{p})$ and $w B 97 X D / 6-311++G(d, p))$ in acetonitrile $(\mathrm{MeCN})$, taking into account nonspecific solvent ef- 
fects (SMD model). The active intermediates of the reaction- $\mathrm{XH} \cdots \mathrm{HB}$ dihydrogen-bonded (DHB) complexes for $\left[\mathrm{BH}_{4}\right]^{-}$and $\mathrm{ClH} \cdots \mathrm{B}_{3}$ complexes for $\left[\mathrm{B}_{6} \mathrm{H}_{6}\right]^{2-}$-were identified, and their geometric parameters, energetic characteristics, and electron structures were deduced. In the case of $\left[\mathrm{B}_{6} \mathrm{H}_{6}\right]^{2-}$, an electrophile-induced nucleophilic substitution (EINS) mechanism of halogenation was established. The obtained values of activation energies of $\mathrm{H}_{2}$ elimination were relatively high. Nonetheless, the identified pattern in the changes of electronic characteristics, the reactivity of $\mathrm{B}-\mathrm{H}$ bonds (such as thermodynamic hydridicity and acidity of halogenated products) and the structures of $\mathrm{H}_{2}$ complexes suggests that it should be possible to control the degree of halogenation and carry out the targeted synthesis of products with a low degree of substitution using a wide range of synthetic approaches.

Supplementary Materials: The following are available online, Table S1. M06-computed geometric parameters (distances $r_{(X-Y)}$ in $\AA$, angles in ${ }^{\circ}$ ) of dihydrogen-bonded (DHB) complexes (INTn ${ }^{\mathrm{DHB}}$ ) of $\left[\mathrm{BH}_{(4-\mathrm{x})} \mathrm{X}_{\mathrm{x}}\right]-(\mathrm{x}=0-3)$ with $\mathrm{HX}(\mathrm{X}=\mathrm{F}, \mathrm{Cl}, \mathrm{Br})$ and their energies. Table S2. M06-computed geometric parameters (distances $\mathrm{r}_{(\mathrm{X}-\mathrm{Y})}$ in $\AA$, angles in ${ }^{\circ}$ ) of $\mathrm{H}_{2}$ complexes of $\mathrm{X}^{-}\left[\left(\mathrm{H}_{2}\right) \mathrm{BH}_{(4-\mathrm{x})} \mathrm{X}_{\mathrm{x}}\right]-(\mathrm{x}=1-2, \mathrm{X}=\mathrm{Cl}$, $\mathrm{Br})\left(\mathrm{INT}^{\mathrm{H} 2}\right)$ and their energies. Table S3. Hydride affinity $\left(\mathrm{HA}_{298 \mathrm{~K}}\right.$ in $\left.\mathrm{kcal} / \mathrm{mol}\right)$ of $\left[\mathrm{BH}_{(4-\mathrm{x})} \mathrm{X}_{\mathrm{x}}\right]^{-}$ $(\mathrm{x}=0-3)(\mathrm{X}=\mathrm{F}, \mathrm{Cl}, \mathrm{Br})$. Hybridization of boron orbitals in B-H moieties, QTAIM delocalization indices (DI) of $\mathrm{BH}$ bond in of $\left[\mathrm{BH}_{(4-\mathrm{x})} \mathrm{X}_{\mathrm{x}}\right]^{-}(\mathrm{x}=0-3, \mathrm{X}=\mathrm{F}, \mathrm{Cl}, \mathrm{Br})$. Hydride $\left(\mathrm{HDA}_{\mathrm{MeCN}}\right.$ in $\left.\mathrm{kcal} / \mathrm{mol}\right)$ and proton $\left(\mathrm{PDA}_{\mathrm{MeCN}}\right.$ in $\mathrm{kcal} / \mathrm{mol}$ ) donor abilities for $\mathrm{Li}_{[}\left[\mathrm{BH}_{(4-\mathrm{x})} \mathrm{X}_{\mathrm{x}}\right]$ in MeCN. Table S4. QTAIM delocalization indices (DI) and Wiberg bond indices (WBI) for $\mathrm{H} \cdots \mathrm{H}$ contacts, their differences for $\mathrm{XH}$ and $\mathrm{HB}$ bonds, and hybridization of boron orbitals in $\mathrm{BH}$ moieties of M06-computed geometries of DHB complexes for $\left[\mathrm{BH}_{(4-\mathrm{x})} \mathrm{X}_{\mathrm{x}}\right]^{-}(\mathrm{x}=0-3)$ with $\mathrm{HX}(\mathrm{X}=\mathrm{F}, \mathrm{Cl}, \mathrm{Br})\left(\mathrm{INTn}{ }^{\mathrm{DHB}}\right)$. Table S5. Free Gibbs activation energy in acetonitrile $\left(\Delta \mathrm{G}^{\circ}{ }_{\mathrm{MeCN}}{ }^{\ddagger}\right.$ in $\left.\mathrm{kcal} / \mathrm{mol}\right)$ of the transition state of $\mathrm{H}_{2}$ elimination $\left(\mathrm{TSn}^{\mathrm{ELIM}}{ }_{\mathrm{HX}}\right)$, and concerted transition state of proton-hydride transfer $/ \mathrm{H}_{2}$ elimination $\left(\mathrm{TSn}^{\mathrm{CONC}}{ }_{\mathrm{HX}}\right)$ for the reaction of $\mathrm{BH}_{4}{ }^{-}$with $\mathrm{HX}(\mathrm{X}=\mathrm{F}, \mathrm{Cl}, \mathrm{Br})$-and their M06-optimized geometric parameters. Table S6. Free Gibbs activation energy in acetonitrile $\left(\Delta \mathrm{G}^{\circ} \mathrm{MeCN}{ }^{\ddagger}\right.$ in $\left.\mathrm{kcal} / \mathrm{mol}\right)$ of the transition state of $\mathrm{H}_{2}$ elimination $\left(\mathrm{TSn}^{\mathrm{ELIM}}{ }_{\mathrm{HX}}\right.$ ) and concerted transition state of proton-hydride transfer $/ \mathrm{H}_{2}$ elimination $\left(\mathrm{TSn}^{\mathrm{CONC}} \mathrm{HX}\right)$ for the reaction of $\mathrm{BH}_{4}{ }^{-}$with $\mathrm{HX}(\mathrm{X}=\mathrm{F}, \mathrm{Cl}, \mathrm{Br})$ and their wB97XD-optimized geometric parameters. Table S7. Free Gibbs activation energy in dichloromethane $\left(\Delta \mathrm{G}^{\circ} \mathrm{DCM}^{\ddagger}\right.$ in $\left.\mathrm{kcal} / \mathrm{mol}\right)$ of the concerted transition state of proton-hydride transfer $/ \mathrm{H}_{2}$ elimination ( $\mathrm{TS}^{\mathrm{CONC}}{ }_{\mathrm{ROH}}$ ) for the reaction of $\mathrm{BH}_{4}{ }^{-}$with $\mathrm{HOR}\left[\mathrm{ROH}=\mathrm{MeOH}, \mathrm{CF}_{3} \mathrm{CH}_{2} \mathrm{OH}(\mathrm{TFE}),\left(\mathrm{CF}_{3}\right)_{2} \mathrm{CHOH}\right.$ (HFIP)] and their M06optimized geometric parameters. Table S8. Hydride $\left(\mathrm{HDA}_{\mathrm{MeCN}}\right.$ in $\left.\mathrm{kcal} / \mathrm{mol}\right)$ and proton $\left(\mathrm{PDA}_{\mathrm{MeCN}}\right.$ in $\mathrm{kcal} / \mathrm{mol})$ donor abilities for $\left[\mathrm{B}_{6} \mathrm{H}_{(6-x)} \mathrm{Cl}_{\mathrm{x}}\right]^{2-}(\mathrm{x}=0-5)$ in MeCN. Table S9. M06-computed geometric (distances $r_{(X-Y)}$ in $\AA$, angles in degrees) parameters of hydrogen-bonded complexes of $\left[\mathrm{B}_{6} \mathrm{H}_{(6-x)} \mathrm{Cl}_{\mathrm{x}}\right]^{2-}(\mathrm{x}=0-5)$ with $\mathrm{HCl}\left(\mathrm{INTn}^{\mathrm{HB}}\right)$ and their energies. Table S10. M06-computed geometric (distances $r_{(X-Y)}$ in $\AA$, angles in degrees) parameters of hydrogen-bonded complexes of $\mathrm{Cl}^{-}$[ac $\left.^{\mathrm{fa}} \mathrm{HB}_{6} \mathrm{H}_{(6-\mathrm{x})} \mathrm{Cl}_{\mathrm{x}}\right]^{-}(\mathrm{x}=0-5)$ with $\mathrm{HCl}$ and their energies. Table S11. M06-computed geometric parameters (distances $\mathrm{r}_{(\mathrm{X}-\mathrm{Y})}$ in $\AA$, angles in ${ }^{\circ}$ ) of $\mathrm{H}_{2}$ complexes of $\mathrm{Cl}^{-}\left[\left(\mathrm{H}_{2}\right) \mathrm{B}_{6} \mathrm{H}_{(5-\mathrm{x})} \mathrm{Cl}_{\mathrm{x}}\right]^{-}(\mathrm{n}=0-5)$ $\left(\mathrm{INTn}^{\mathrm{H}} 2\right)$ and their energies. Table S12. Activation barriers $\left(\Delta \mathrm{G}^{\circ} \mathrm{MeCN}^{\ddagger}\right.$, in $\left.\mathrm{kcal} / \mathrm{mol}\right)$ for TSs for the reaction of $\left[\mathrm{B}_{6} \mathrm{H}_{6}\right]^{2-}$ with $\mathrm{HCl}\left(\mathrm{pK}_{\mathrm{a}}{ }^{\mathrm{MeCN}}=10.3\right)$ in $\mathrm{MeCN}$, computed at the $\mathrm{wB} 97 \mathrm{XD} / 6-311++\mathrm{G}(\mathrm{d}, \mathrm{p})$ theory level. Figure S1. M06-calculated energy profile $\left(\Delta \mathrm{G}^{\circ} \mathrm{MeCN}\right.$ in $\left.\mathrm{kcal} / \mathrm{mol}\right)$ of the reaction of $\mathrm{BH}_{4}{ }^{-}$with $\mathrm{HF}$ in MeCN. Figure S2. wB97XD-calculated energy profile $\left(\Delta \mathrm{G}^{\circ} \mathrm{MeCN}\right.$ in $\left.\mathrm{kcal} / \mathrm{mol}\right)$ of the reaction of $\mathrm{BH}_{4}{ }^{-}$with $\mathrm{HF}$ in MeCN. Figure S3. wB97XD-calculated energy profile $\left(\Delta \mathrm{G}^{\circ} \mathrm{MeCN}\right.$ in $\mathrm{kcal} / \mathrm{mol}$ ) of the reaction of $\mathrm{BH}_{4}{ }^{-}$with $\mathrm{HCl}$ in $\mathrm{MeCN}$. Figure S4. M06-calculated energy profile $\left(\Delta \mathrm{G}^{\circ} \mathrm{MeCN}\right.$ in $\left.\mathrm{kcal} / \mathrm{mol}\right)$ of the reaction of $\mathrm{BH}_{4}{ }^{-}$with $\mathrm{HBr}$ in MeCN. Figure S5. wB97XD-calculated energy profile $\left(\Delta \mathrm{G}^{\circ}{ }_{\mathrm{MeCN}}\right.$ in $\left.\mathrm{kcal} / \mathrm{mol}\right)$ of the reaction of $\mathrm{BH}_{4}{ }^{-}$with $\mathrm{HBr}$ in $\mathrm{MeCN}$. Figure S6. M06-optimized geometries of the protonated forms $\left[{ }^{\mathrm{fac}} \mathrm{HB}_{6} \mathrm{H}_{(6-x)} \mathrm{Cl}_{\mathrm{x}}\right]^{-}(\mathrm{n}=0-4)$ and their free Gibbs formation energies $\left(\Delta \mathrm{G}_{f}{ }^{\circ \mathrm{MeCN}}\right.$ in $\left.\mathrm{kcal} / \mathrm{mol}\right)$. Figure S7. wB97XD-calculated energy profile of halogenation of $\left[\mathrm{B}_{6} \mathrm{H}_{(6-\mathrm{x})} \mathrm{Cl}_{\mathrm{x}}\right]^{2-}(\mathrm{x}=0-5)$ by $\mathrm{HCl}$ for the pathway: $\left[\mathrm{B}_{6} \mathrm{H}_{6}\right]^{2-} \rightarrow 1-\left[\mathrm{B}_{6} \mathrm{H}_{5} \mathrm{Cl}\right]^{2-} \rightarrow$ $1,2-\left[\mathrm{B}_{6} \mathrm{H}_{4} \mathrm{Cl}_{2}\right]^{2-}(c i s) \rightarrow 1,2,3-\left[\mathrm{B}_{6} \mathrm{H}_{3} \mathrm{Cl}_{3}\right]^{2-}(\mathrm{fac}) \rightarrow 1,2,3,4-\left[\mathrm{B}_{6} \mathrm{H}_{2} \mathrm{Cl}_{4}\right]^{2-}(c i s) \rightarrow 1,2,3,4,6-\left[\mathrm{B}_{6} \mathrm{HCl}_{5}\right]^{2-}$. Animation of the vibration motion at the imaginary frequency for the TSs (GIF). Cartesian coordinates and electronic energies (in Hartrees) for the calculated species (XYZ).

Author Contributions: Funding acquisition, I.E.G.; Investigation, I.E.G.; Resources, O.A.F.; Supervision, L.M.E. and E.S.S.; Visualization, I.E.G.; Writing—original draft, I.E.G.; Writing-review \& editing, O.A.F. and N.V.B. All authors have read and agreed to the published version of the manuscript. 
Funding: This research was financially supported by the Russian Science Foundation (RSF grant number 19-73-00309). L.M.E. and E.S.S. thank the Ministry of Science and Higher Education of the Russian Federation for the partial support of this research.

Institutional Review Board Statement: Not applicable.

Informed Consent Statement: Not applicable.

Data Availability Statement: Not applicable.

Conflicts of Interest: The authors declare no conflict of interest.

Sample Availability: Not available.

\section{References}

1. Lipping, L.; Leito, I.; Koppel, I.; Krossing, I.; Himmel, D.; Koppel, I.A. Superacidity of closo-Dodecaborate-Based Brønsted Acids: A DFT Study. J. Phys. Chem. A 2015, 119, 735-743. [CrossRef]

2. Rohdenburg, M.; Mayer, M.; Grellmann, M.; Jenne, C.; Borrmann, T.; Kleemiss, F.; Azov, V.A.; Asmis, K.R.; Grabowsky, S.; Warneke, J. Superelectrophilic Behavior of an Anion Demonstrated by the Spontaneous Binding of Noble Gases to [B $\left.\mathrm{B}_{12} \mathrm{Cl}_{11}\right]^{-}$. Angew. Chem. Int. Ed. 2017, 56, 7980-7985. [CrossRef]

3. Nava, M.; Stoyanova, I.V.; Cummings, S.; Stoyanov, E.S.; Reed, C.A. The Strongest Brønsted Acid: Protonation of Alkanes by $\mathrm{H}\left(\mathrm{CHB}_{11} \mathrm{~F}_{11}\right)$ at Room Temperature. Angew. Chem. Int. Ed. 2013, 53, 1131-1134. [CrossRef]

4. Jenne, $\mathrm{C} . ;$ Keßler, M.; Warneke, J. Protic Anions $\left[\mathrm{H}\left(\mathrm{B}_{12} \mathrm{X}_{12}\right)\right]^{-}(\mathrm{X}=\mathrm{F}, \mathrm{Cl}, \mathrm{Br}, \mathrm{I})$ That Act as Brønsted Acids in the Gas Phase. Chem. A Eur. J. 2015, 21, 5887-5891. [CrossRef]

5. Avelar, A.; Tham, F.S.; Reed, C.A. Superacidity of Boron Acids $\mathrm{H}_{2}\left(\mathrm{~B}_{12} \mathrm{X}_{12}\right)(\mathrm{X}=\mathrm{Cl}, \mathrm{Br})$. Angew. Chem. Int. Ed. 2009, 48, 3491-3493. [CrossRef]

6. Bolli, C.; Derendorf, J.; Jenne, C.; Keßler, M. Halogenatedcloso-Dodecaborate Anions Stabilize Weakly Bound $\left[\left(\mathrm{Me}_{3} \mathrm{NH}\right)_{3} \mathrm{X}\right]^{2+}$ $(\mathrm{X}=\mathrm{Cl}, \mathrm{Br})$ Dications in the Solid State. Eur. J. Inorg. Chem. 2017, 2017, 4552-4558. [CrossRef]

7. Geis, V.; Guttsche, K.; Knapp, C.; Scherer, H.; Uzun, R. Synthesis and characterization of synthetically useful salts of the weakly-coordinating dianion $\left[\mathrm{B}_{12} \mathrm{Cl}_{12}\right]^{2-}$. Dalton Trans. 2009, 10, 2687-2694. [CrossRef] [PubMed]

8. Zhou, N.; Zhao, G.; Dong, K.; Sun, J.; Shao, H. Investigations on a series of novel ionic liquids containing the $\left[\mathrm{closo} \mathrm{B}_{12} \mathrm{Cl}_{12}\right]^{2-}$ dianion. RSC Adv. 2012, 2, 9830-9838. [CrossRef]

9. Li, S.; Qiu, P.; Kang, J.; Ma, Y.; Zhang, Y.; Yan, Y.; Jensen, T.R.; Guo, Y.; Zhang, J.; Chen, X. Iodine-Substituted Lithium/Sodium closo-Decaborates: Syntheses, Characterization, and Solid-State Ionic Conductivity. ACS Appl. Mater. Interfaces 2021, 13, 17554-17564. [CrossRef]

10. Mohtadi, R. Beyond Typical Electrolytes for Energy Dense Batteries. Molecules 2020, 25, 1791. [CrossRef] [PubMed]

11. Agarwal, H.K.; Hasabelnaby, S.; Tiwari, R.; Tjarks, W. Boron cluster (radio) halogenation in biomedical research. In Boron Science: New Technologies and Applications; Hosmane, N.S., Ed.; CRC Press: Boca Raton, FL, USA, 2011; pp. 107-144. [CrossRef]

12. Rude, L.H.; Filsø, U.; D'Anna, V.; Spyratou, A.; Richter, B.; Hino, S.; Zavorotynska, O.; Baricco, M.; Sørby, M.; Hauback, B.C.; et al. Hydrogen-fluorine exchange in $\mathrm{NaBH}_{4}-\mathrm{NaBF}_{4}$. Phys. Chem. Chem. Phys. 2013, 15, 18185-18194. [CrossRef]

13. Titov, L.V.; Gavrilova, L.A.; Titova, K.V.; Rosolovskii, V.Y. Ligand redistribution in the $\left(\mathrm{C}_{4} \mathrm{H}_{9}\right)_{4} \mathrm{NBH}_{4}-\left(\mathrm{C}_{4} \mathrm{H}_{9}\right)_{4} \mathrm{NBCl}_{4}$ system. Russ. Chem. Bull. 1978, 27, 1504-1508. [CrossRef]

14. Richter, B.; Ravnsbæk, D.B.; Sharma, M.; Spyratou, A.; Hagemann, H.; Jensen, T.R. Fluoride substitution in LiBH ${ }_{4}$; destabilization and decomposition. Phys. Chem. Chem. Phys. 2017, 19, 30157-30165. [CrossRef] [PubMed]

15. Van Paasschen, J.M.; Hu, M.G.; Peacock, L.A.; Geanangel, R.A. A Convenient Method for Preparing Amine-Haloboranes. Synth . React. Inorg. Met. Chem. 1974, 4, 11-21. [CrossRef]

16. Rohdenburg, M.; Yang, Z.; Su, P.; Bernhardt, E.; Yuan, Q.; Apra, E.; Grabowsky, S.; Laskin, J.; Jenne, C.; Wang, X.-B.; et al. Properties of gaseous closo- $\left[\mathrm{B}_{6} \mathrm{X}_{6}\right]^{2-}$ dianions $(\mathrm{X}=\mathrm{Cl}, \mathrm{Br}, \mathrm{I})$. Phys. Chem. Chem. Phys. 2020, 22, 17713-17724. [CrossRef] [PubMed]

17. Lepšík, M.; Srnec, M.; Hnyk, D.; Grüner, B.; Plešek, J.; Havlas, Z.; Rulíšek, L. exo-Substituent effects in halogenated icosahedral $\left(\mathrm{B}_{12} \mathrm{H}_{12}{ }^{2-}\right)$ and octahedral $\left(\mathrm{B}_{6} \mathrm{H}_{6}{ }^{2-}\right)$ closo-borane skeletons: Chemical reactivity studied by experimental and quantum chemical methods. Collect. Czechoslov. Chem. Commun. 2009, 74, 1-27. [CrossRef]

18. Preetz, W.; Peters, G. The Hexahydro-closo-hexaborate Dianion $\left[\mathrm{B}_{6} \mathrm{H}_{6}\right]^{2-}$ and Its Derivatives. Eur. J. Inorg. Chem. 1999, $1999,1831-1846$. [CrossRef]

19. Zhou, Y.; Fang, C.; Fang, Y.; Zhu, F.; Liu, H.; Ge, H. Hydrogen generation mechanism of spontaneous hydrolysis: A sight from ab initio calculation. Int. J. Hydrogen Energy 2016, 41, 22668-22676. [CrossRef]

20. Golub, I.E.; Filippov, O.A.; Gulyaeva, E.S.; Gutsul, E.I.; Belkova, N.V. The Interplay of Proton Accepting and Hydride Donor Abilities in the Mechanism of Step-Wise Boron Hydrides Alcoholysis. Inorg. Chim. Acta 2017, 456, 113-119. [CrossRef]

21. Filippov, O.A.; Filin, A.M.; Tsupreva, V.N.; Belkova, N.V.; Lledós, A.; Ujaque, G.; Epstein, L.M.; Shubina, E.S. Proton-Transfer and $\mathrm{H}_{2}$-Elimination Reactions of Main-Group Hydrides $\mathrm{EH}_{4}^{-}(\mathrm{E}=\mathrm{B}, \mathrm{Al}, \mathrm{Ga})$ with Alcohols. Inorg. Chem. 2006, 45, 3086-3096. [CrossRef] 
22. Drozdova, V.V.; Zhizhin, K.; Malinina, E.A.; Polyakova, I.N.; Kuznetsov, N. Reaction of the closo-decaborate anion $\mathrm{B}_{10} \mathrm{H}_{10}{ }^{2-}$ with $^{-}$ dichloroethane in the presence of hydrogen halides. Russ. J. Inorg. Chem. 2007, 52, 996-1001. [CrossRef]

23. Drozdova, V.V.; Malinina, E.A.; Polyakova, I.N.; Razgonyaeva, G.A.; Zhizhin, K.; Kuznetsov, N. Reactions of the closododecaborate anion $\mathrm{B}_{12} \mathrm{H}_{12}{ }^{2-}$ with hydrogen halides in dichloroethane. Russ. J. Inorg. Chem. 2007, 52, 52-57. [CrossRef]

24. Wiedner, E.S.; Chambers, M.; Pitman, C.; Bullock, R.M.; Miller, A.J.M.; Appel, A.M. Thermodynamic Hydricity of Transition Metal Hydrides. Chem. Rev. 2016, 116, 8655-8692. [CrossRef] [PubMed]

25. Waldie, K.M.; Ostericher, A.L.; Reineke, M.H.; Sasayama, A.F.; Kubiak, C.P. Hydricity of Transition-Metal Hydrides: Thermodynamic Considerations for CO2 Reduction. ACS Catal. 2018, 8, 1313-1324. [CrossRef]

26. Alherz, A.; Lim, C.-H.; Hynes, J.T.; Musgrave, C.B. Predicting Hydride Donor Strength via Quantum Chemical Calculations of Hydride Transfer Activation Free Energy. J. Phys. Chem. B 2018, 122, 1278-1288. [CrossRef] [PubMed]

27. Heiden, Z.M.; Lathem, A.P. Establishing the Hydride Donor Abilities of Main Group Hydrides. Organometallics 2015, 34, 1818-1827. [CrossRef]

28. Horn, M.; Schappele, L.H.; Lang-Wittkowski, G.; Mayr, H.; Ofial, A.R. Towards a Comprehensive Hydride Donor Ability Scale. Chem. A Eur. J. 2012, 19, 249-263. [CrossRef]

29. Golub, I.E.; Filippov, O.A.; Kulikova, V.A.; Belkova, N.V.; Epstein, L.M.; Shubina, E.S. Thermodynamic Hydricity of Small Borane Clusters and Polyhedral closo-Boranes. Molecules 2020, 25, 2920. [CrossRef]

30. Golub, I.E.; Filippov, O.A.; Belkova, N.V.; Epstein, L.M.; Shubina, E.S. Hydride donating abilities of the tetracoordinated boron hydrides. J. Organomet. Chem. 2018, 865, 247-256. [CrossRef]

31. Landmann, J.; Keppner, F.; Hofmann, D.B.; Sprenger, J.A.P.; Häring, M.; Zottnick, S.H.; Müller-Buschbaum, K.; Ignat'Ev, N.V.; Finze, M. Deprotonation of a Hydridoborate Anion. Angew. Chem. Int. Ed. 2017, 56, 2795-2799. [CrossRef]

32. Weiss, H.G.; Shapiro, I. Diborane from the Sodium Borohydride-Sulfuric Acid Reaction. J. Am. Chem. Soc. 1959, 81, 6167-6168. [CrossRef]

33. Hugas, D.; Simon, S.; Duran, M.; Guerra, C.F.; Bickelhaupt, F.M. Dihydrogen Bonding: Donor-Acceptor Bonding (AH ‥HX) versus the $\mathrm{H}_{2}$ Molecule (A- $\left.\mathrm{H}_{2}-\mathrm{X}\right)$. Chem. Eur. J. 2009, 15, 5814-5822. [CrossRef] [PubMed]

34. Shubina, E.S.; Bakhmutova, E.V.; Saitkulova, L.N.; Epstein, L.M. Intermolecular hydrogen bonds BH $\cdots$ HX in solution. Mendeleev Commun. 1997, 7, 83-84. [CrossRef]

35. Epstein, L.M.; Shubina, E.S.; Bakhmutova, E.V.; Saitkulova, L.N.; Bakhmutov, V.I.; Chistyakov, A.L.; Stankevich, I.V. Unusual Hydrogen Bonds with a Hydride Atom in Boron Hydrides Acting as Proton Acceptor. Spectroscopic and Theoretical Studies. Inorg. Chem. 1998, 37, 3013-3017. [CrossRef]

36. Belkova, N.V.; Shubina, E.S.; Epstein, L.M. Diverse World of Unconventional Hydrogen Bonds. Accounts Chem. Res. 2005, 38, 624-631. [CrossRef] [PubMed]

37. Filippov, O.A.; Belkova, N.V.; Epstein, L.M.; Shubina, E.S. Chemistry of boron hydrides orchestrated by dihydrogen bonds. J. Organomet. Chem. 2013, 747, 30-42. [CrossRef]

38. Belkova, N.V.; Epstein, L.M.; Filippov, O.A.; Shubina, E.S. Hydrogen and Dihydrogen Bonds in the Reactions of Metal Hydrides. Chem. Rev. 2016, 116, 8545-8587. [CrossRef]

39. Abraham, M.H.; Acree, W.E. Descriptors for the hydrogen halides, their solution properties and hydrogen- bonding acidity and basicity: Comparison of the latter with gas phase data. J. Mol. Liq. 2019, 275, 667-673. [CrossRef]

40. Allred, A.; Rochow, E. A scale of electronegativity based on electrostatic force. J. Inorg. Nucl. Chem. 1958, 5, 264-268. [CrossRef]

41. Grant, D.J.; Dixon, D.A.; Camaioni, D.; Potter, R.G.; Christe, K.O. Lewis Acidities and Hydride, Fluoride, and $X^{-}$Affinities of the $\mathrm{BH}_{3-\mathrm{n}} \mathrm{X}_{\mathrm{n}}$ Compounds for $\left(\mathrm{X}=\mathrm{F}, \mathrm{Cl}, \mathrm{Br}, \mathrm{I}, \mathrm{NH}_{2}, \mathrm{OH}\right.$, and $\left.\mathrm{SH}\right)$ from Coupled Cluster Theory. Inorg. Chem. 2009, 48, 8811-8821. [CrossRef]

42. Steudel, R. 6. Boron. In Chemistry of the Non-Metals; De Gruyter: Berlin, Germany, 2020; pp. 215-264.

43. Grabowski, S.J. Two faces of triel bonds in boron trihalide complexes. J. Comput. Chem. 2017, 39, 472-480. [CrossRef] [PubMed]

44. Nicoleti, C.R.; Marini, V.G.; Zimmermann, L.M.; Machado, V.G. Anionic chromogenic chemosensors highly selective for fluoride or cyanide based on 4-(4-Nitrobenzylideneamine)phenol. J. Braz. Chem. Soc. 2012, 23, 1488-1500. [CrossRef]

45. Kütt, A.; Tshepelevitsh, S.; Saame, J.; Lõkov, M.; Kaljurand, I.; Selberg, S.; Leito, I. Strengths of Acids in Acetonitrile. Eur. J. Org. Chem. 2021, 2021, 1407-1419. [CrossRef]

46. Jessop, P.G.; Morris, R. Reactions of transition metal dihydrogen complexes. Coord. Chem. Rev. 1992, 121, 155-284. [CrossRef]

47. Gao, S.; Wu, W.; Mo, Y. The B-H $\cdots \mathrm{H}-\mathrm{P}$ Dihydrogen Bonding in Ion Pair Complexes $\left[\left(\mathrm{CF}_{3}\right)_{3} \mathrm{BH}^{-}\right]\left[\mathrm{HPH}_{3-\mathrm{n}}(\mathrm{Me})_{\mathrm{n}}{ }^{+}\right](\mathrm{n}=0-3)$ and Its Implication in $\mathrm{H}_{2}$ Elimination and Activation Reactions. J. Phys. Chem. A 2009, 113, 8108-8117. [CrossRef] [PubMed]

48. Marincean, S.; Jackson, J. Quest for IR-Pumped Reactions in Dihydrogen-Bonded Complexes. J. Phys. Chem. A 2004, 108, 5521-5526. [CrossRef]

49. Filippov, O.A.; Belkova, N.V.; Epstein, L.M.; Lledos, A.; Shubina, E.S. Hydrogen-deuterium exchange in hydride chemistry: Dihydrogen bonded complexes as key intermediates. Comput. Theor. Chem. 2012, 998, 129-140. [CrossRef]

50. Könczöl, L.; Makkos, E.; Bourissou, D.; Szieberth, D. Computational Evidence for a New Type of $\eta^{2}-\mathrm{H}_{2}$ Complex: When Main-Group Elements Act in Concert To Emulate Transition Metals. Angew. Chem. 2012, 124, 9659-9662. [CrossRef]

51. Könczöl, L.; Turczel, G.; Szpisjak, T.; Szieberth, D. The stability of $\eta_{2}-\mathrm{H}_{2}$ borane complexes: A theoretical investigation. Dalton Trans. 2014, 43, 13571-13577. [CrossRef] 
52. Golub, I.E.; Gulyaeva, E.S.; Filippov, O.A.; Dyadchenko, V.P.; Belkova, N.V.; Epstein, L.M.; Arkhipov, D.E.; Shubina, E.S. Dihydrogen Bond Intermediated Alcoholysis of Dimethylamine-Borane in Nonaqueous Media. J. Phys. Chem. A 2015, 119, $3853-3868$. [CrossRef]

53. Sivaev, I.B.; Bregadze, V.I. Lewis acidity of boron compounds. Coord. Chem. Rev. 2014, 270-271, 75-88. [CrossRef]

54. Bregadze, I.V.; Timofeev, S.V.; Sivaev, I.B.; A Lobanova, I. Substitution reactions at boron atoms in metallacarboranes. Russ. Chem. Rev. 2004, 73, 433-453. [CrossRef]

55. Schaeffer, R.; Johnson, Q.; Smith, G.S. The Crystal and Molecular Structure of Tetramethylammonium Hexahydrohexaborate. Inorg. Chem. 1965, 4, 917-918. [CrossRef]

56. Schleyer, P.V.R.; Najafian, K.; Mebel, A.M. The Largecloso-Borane Dianions, $\mathrm{B}_{\mathrm{n}} \mathrm{H}_{\mathrm{n}}{ }^{2-}(\mathrm{n}=13-17)$ Are Aromatic, Why Are They Unknown? Inorg. Chem. 1998, 37, 6765-6772. [CrossRef]

57. Axtell, J.C.; Saleh, L.M.A.; Qian, E.A.; Wixtrom, A.I.; Spokoyny, A.M. Synthesis and Applications of Perfunctionalized Boron Clusters. Inorg. Chem. 2018, 57, 2333-2350. [CrossRef] [PubMed]

58. Kuznetsov, I.Y.; Vinitskii, D.; Solntsev, K.A.; Kuznetsov, N.T.; Butman, L. New hydroboron anion B $\mathrm{H}_{7}$. Dokl. Akad. Nauk SSSR 1985, 283, 873-877.

59. Preetz, W.; Heinrich, A.; Thesing, J. closo-Halogenohydrohexaborate, IV Protonierung, Deuterierung und Schwingungsspektren von claso-Hexaboraten / closo-Halogenohydrohexaborate, IV Protonation, Deuteration and Vibrational Spectra of closoHexaborates. Z. Naturforschung B 1988, 43, 1319-1326. [CrossRef]

60. Hofmann, K.; Prosenc, M.H.; Albert, B.R. A new 4c-2e bond in $\mathrm{B}_{6} \mathrm{H}_{7}{ }^{-}$. Chem. Commun. 2007, 29, 3097-3099. [CrossRef] [PubMed]

61. Brint, P.; Healy, E.; Spalding, T.R.; Whelan, T. Bonding in clusters. Part 3. Protonation of nido-pentaborane(9), nido-hexaborane(10), and closo-hexaborate(6)(2-). J. Chem. Soc. Dalton Trans. 1981, 10, 2515-2522. [CrossRef]

62. Minyaev, R.; Minkin, V.; Gribanova, T.N.; Starikov, A. Structure and stability of closo-hexaboranes and their heteroanalogs. Russ. Chem. Bull. 2004, 53, 1159-1167. [CrossRef]

63. Zabardasti, A.; Salehnassaj, $\mathrm{M}$. The $\mathrm{B}_{3}$ triangle faces of $\mathrm{B}_{6} \mathrm{H}_{6}{ }^{2-}$ as the preferred electron donor sites for successive interactions with $\mathrm{HF}$ in $\mathrm{B}_{6} \mathrm{H}_{6}(\mathrm{HF})^{2-}$ complexes $(\mathrm{n}=1-8)$. Polyhedron 2019, 157, 521-529. [CrossRef]

64. Filippov, O.A.; Tsupreva, V.N.; Epstein, L.M.; Lledos, A.; Shubina, E.S. Intermolecular HH Vibrations of Dihydrogen Bonded Complexes $\mathrm{H}_{3} \mathrm{EH}^{-} \ldots \mathrm{HOR}$ in the Low-Frequency Region: Theory and IR Spectra. J. Phys. Chem. A 2008, 112, 8198-8204. [CrossRef]

65. Shubina, E.; Bakhmutova, E.; Filin, A.; Sivaev, I.; Teplitskaya, L.; Chistyakov, A.; Stankevich, I.; Bakhmutov, V.; Bregadze, V.; Epstein, L. Dihydrogen bonding of decahydro-closo-decaborate(2-) and dodecahydro-closo-dodecaborate(2-) anions with proton donors: Experimental and theoretical investigation. J. Organomet. Chem. 2002, 657, 155-162. [CrossRef]

66. Rahmani, A.; Zabardasti, A.; Kakanejadifard, A. Intermolecular complexes of $\left[\mathrm{B}_{6} \mathrm{H}_{6}\right]^{2-}$ with $\mathrm{nH} 2(\mathrm{n}=1-8)$ molecules: A theoretical study. Struct. Chem. 2018, 30, 669-680. [CrossRef]

67. Mebel, A.M.; Schleyer, P.V.R.; Najafian, K.; Charkin, O.P. Structure and Nonrigidity of $\mathrm{B}_{9} \mathrm{H}_{9}{ }^{2-}$ and $\mathrm{B}_{9} \mathrm{H}_{10}{ }^{-}$. Comparisons of $\mathrm{B}_{\mathrm{n}} \mathrm{H}_{\mathrm{n}}{ }^{2-}$ and $\mathrm{B}_{\mathrm{n}} \mathrm{H}_{\mathrm{n}+1}$ - Systems. Inorg. Chem. 1998, 37, 1693-1703. [CrossRef]

68. Zhdanov, A.P.; Voinova, V.V.; Klyukin, I.N.; Kubasov, A.S.; Zhizhin, K.; Kuznetsov, N.T. New Synthesis Method of NMonosubstituted Ammonium-closo-Decaborates. J. Clust. Sci. 2019, 30, 1327-1333. [CrossRef]

69. Kochnev, V.K.; Avdeeva, V.V.; Malinina, E.A.; Kuznetsov, N.T. Theoretical study of H2 elimination from $\left[\mathrm{B}_{\mathrm{n}} \mathrm{H}_{\mathrm{n}+1}\right]^{-}$monoanions ( $\mathrm{n}=6-9,11)$. Russ. J. Inorg. Chem. 2014, 59, 1268-1275. [CrossRef]

70. Fritze, J.; Preetz, W.; Marsmann, H.C. closo-Halogenohydrohexaborate, II ${ }^{11}$ B-NMR-Spektren der closo-Halogenohydrohexaborate $\mathrm{X}_{\mathrm{n}} \mathrm{B}_{6} \mathrm{H}_{6-\mathrm{n}}{ }^{2-}, \mathrm{n}=0-6 ; \mathrm{X}=\mathrm{Cl}, \mathrm{Br}, \mathrm{I} /$ closo-Halogenohydrohexaborate, $\mathrm{II}^{11} \mathrm{~B}$ NMR Spectra of the closo-Halogenohydrohexaborates $\mathrm{X}_{\mathrm{n}} \mathrm{B}_{6} \mathrm{H}_{6-\mathrm{n}}{ }^{2-}, \mathrm{n}=0-6 ; \mathrm{X}=\mathrm{Cl}, \mathrm{Br}, \mathrm{I}$. Z. Naturforschung $B$ 1987, 42, 287-292. [CrossRef]

71. Preetz, W.; Fritze, J. closo-Halogenohydrohexaborate, I Darstellung der reinen closo-Halogenohydrohexaborate $\mathrm{X}_{n} \mathrm{~B}_{6} \mathrm{H}_{6-\mathrm{n}}{ }^{2-}$ $\mathrm{n}=1-6, \mathrm{X}=\mathrm{Cl}, \mathrm{Br}$, I, einschlieftlich der Stereoisomeren/closo-Halogenohydrohexaborate, I Preparation of the Pure closoHalogenohydrohexaborates $\mathrm{X}_{\mathrm{n}} \mathrm{B}_{6} \mathrm{H}_{6-\mathrm{n}}{ }^{2-}, \mathrm{n}=1-6 . \mathrm{X}=\mathrm{Cl}, \mathrm{Br}$, I, Including the Stereoisomers. Z. Naturforschung B 1987, 42, 282-286. [CrossRef]

72. Heinrich, A.; Preetz, W.; Marsmann, H.C. ${ }^{11}$ B-NMR-Spektren von Alkyl-, Halogeno- und Rhodanohydrohexaboraten / ${ }^{11}$ B NMR Spectra of Alkyl-, Halogeno- and Rhodanohydrohexaborates. Z. Naturforschung B 1988, 43, 1647-1652. [CrossRef]

73. Voronova, E.D.; Golub, I.E.; Pavlov, A.; Belkova, N.V.; Filippov, O.A.; Epstein, L.M.; Shubina, E.S. Dichotomous Si-H Bond Activation by Alkoxide and Alcohol in Base-Catalyzed Dehydrocoupling of Silanes. Inorg. Chem. 2020, 59, 12240-12251. [CrossRef]

74. Zhao, Y.; Truhlar, D.G. The M06 suite of density functionals for main group thermochemistry, thermochemical kinetics, noncovalent interactions, excited states, and transition elements: Two new functionals and systematic testing of four M06-class functionals and 12 other functionals. Theor. Chem. Accounts 2008, 120, 215-241. [CrossRef]

75. Marenich, A.V.; Cramer, C.J.; Truhlar, D. Universal Solvation Model Based on Solute Electron Density and on a Continuum Model of the Solvent Defined by the Bulk Dielectric Constant and Atomic Surface Tensions. J. Phys. Chem. B 2009, 113, 6378-6396. [CrossRef] [PubMed]

76. Chai, J.-D.; Head-Gordon, M. Long-range corrected hybrid density functionals with damped atom-atom dispersion corrections. Phys. Chem. Chem. Phys. 2008, 10, 6615-6620. [CrossRef] [PubMed] 
77. Frisch, M.J.; Trucks, G.W.; Schlegel, H.B.; Scuseria, G.E.; Robb, M.A.; Cheeseman, J.R.; Scalmani, G.; Barone, V.; Mennucci, B.; Petersson, G.A.; et al. Gaussian 09, Revision D.01; Gaussian Inc.: Wallingford, CT, USA, 2009.

78. Krishnan, R.S.; Binkley, J.S.; Seeger, R.; Pople, J.A. Self-consistent molecular orbital methods. XX. A basis set for correlated wave functions. J. Chem. Phys. 1980, 72, 650-654. [CrossRef]

79. Adrienko, G.A. Chemcraft, Version 1.8 (Build 530). 2017. Available online: http://www.chemcraftprog.com (accessed on 17 June 2021).

80. Kelly, C.P.; Cramer, C.J.; Truhlar, D.G. Single-Ion Solvation Free Energies and the Normal Hydrogen Electrode Potential in Methanol, Acetonitrile, and Dimethyl Sulfoxide. J. Phys. Chem. B 2006, 111, 408-422. [CrossRef] [PubMed]

81. Wiberg, K. Application of the pople-santry-segal CNDO method to the cyclopropylcarbinyl and cyclobutyl cation and to bicyclobutane. Tetrahedron 1968, 24, 1083-1096. [CrossRef]

82. Mayer, I. Bond order and valence indices: A personal account. J. Comput. Chem. 2006, 28, 204-221. [CrossRef]

83. Glendening, E.D.; Badenhoop, J.K.; Reed, A.E.; Carpenter, J.E.; Bohman, J.A.; Morales, C.; Weindhold, F. NBO 5.0; Theoretical Chemistry Institute, University of Wisconsin: Madison, WI, USA, 2001.

84. Keith, T.A. AIMAll (Version 15.05.18); TK Gristmill Software: Overland Park, KS, USA, 2015.

85. Bader, R.F.W.; Stephens, M.E. Spatial localization of the electronic pair and number distributions in molecules. J. Am. Chem. Soc. 1975, 97, 7391-7399. [CrossRef]

86. Bader, R.F.W.; Streitwieser, A.; Neuhaus, A.; Laidig, K.E.; Speers, P. Electron Delocalization and the Fermi Hole. J. Am. Chem. Soc. 1996, 118, 4959-4965. [CrossRef]

87. Wang, Y.-G.; Werstiuk, N.H. A practical and efficient method to calculate AIM localization and delocalization indices at post-HF levels of theory. J. Comput. Chem. 2003, 24, 379-385. [CrossRef]

88. Matta, C.F.; Boyd, R.J.; Becke, A.D. The Quantum Theory of Atoms in Molecules: From Solid State to DNA and Drug Design; John Wiley \& Sons: Hoboken, NJ, USA, 2007.

89. Bader, R.F.W. Atoms in Molecules: A Quantum Theory (International Series of Monographs on Chemistry); Oxford University Press: Oxford, UK, 1994.

90. Popelier, P.L. Atoms in Molecules: An Introduction; Prentice Hall: London, UK, 2000.

91. Matta, C.; Boyd, R.J. Quantum Theory of Atoms in Molecules: Recent Progress in Theory and Application; Wiley-VCH: New York, NY, USA, 2007.

92. Espinosa, E.; Alkorta, I.; Rozas, I.; Elguero, J.; Molins, E. About the evaluation of the local kinetic, potential and total energy densities in closed-shell interactions. Chem. Phys. Lett. 2001, 336, 457-461. [CrossRef]

93. Espinosa, E.; Molins, E.; Lecomte, C. Hydrogen bond strengths revealed by topological analyses of experimentally observed electron densities. Chem. Phys. Lett. 1998, 285, 170-173. [CrossRef] 